\title{
NNSS Soils Monitoring: Plutonium Valley (CAU 366) FY2012
}

prepared by

Julianne J. Miller, Steve A. Mizell, George Nikolich, Greg McCurdy, and Scott Campbell Desert Research Institute

Nevada System of Higher Education

submitted to

Nevada Site Office

National Nuclear Security Administration

U.S. Department of Energy

Las Vegas, Nevada

September 2012

\section{Publication No.}


Reference herein to any specific commercial product, process, or service by trade name, trademark, manufacturer, or otherwise, does not necessarily constitute or imply its endorsement, recommendation, or favoring by the United States Government or any agency thereof or its contractors or subcontractors. The views and opinions of authors expressed herein do not necessarily state or reflect those of the United States Government or any agency thereof.

This report has been reproduced directly from the best available copy.

Available for sale to the public, in paper, from:

U.S. Department of Commerce

National Technical Information Service

5301 Shawnee Road

Alexandria, VA 22312

Phone: 800.553.6847

Fax: 703.605.6900

Email: orders@ntis.gov

Online ordering: http://www.osti.gov/ordering.htm

Available electronically at http://www.doe.gov/bridge

Available for a processing fee to the U.S. Department of Energy and its contractors, in paper, from:

U.S. Department of Energy

Office of Scientific and Technical Information

P.O. Box 62

Oak Ridge, TN 37831-0062

phone: 423.576 .8401

fax: 423.576 .5728

email: reports@adonis.osti.gov 


\title{
NNSS Soils Monitoring: Plutonium Valley (CAU 366) FY2012
}

\author{
prepared by \\ Julianne J. Miller, Steve A. Mizell, George Nikolich, Greg McCurdy, and Scott Campbell \\ Desert Research Institute \\ Nevada System of Higher Education
}

Publication No.

submitted to

Nevada Site Office

National Nuclear Security Administration

U.S. Department of Energy

Las Vegas, Nevada

September 2012

The work upon which this report is based was supported by the U.S. Department of Energy under Contract \# DE-NA0000939. 
THIS PAGE INTENTIONALLY LEFT BLANK 


\section{CONTENTS}

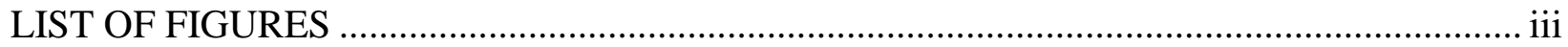

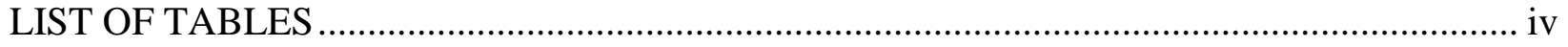

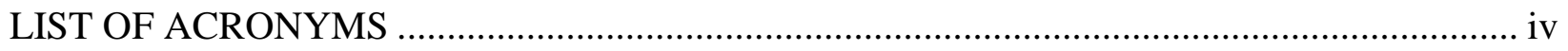

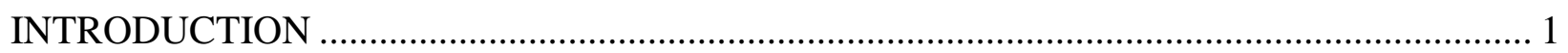

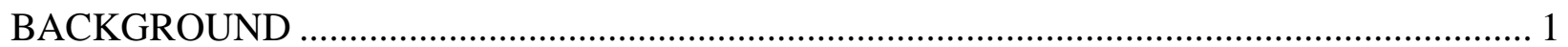

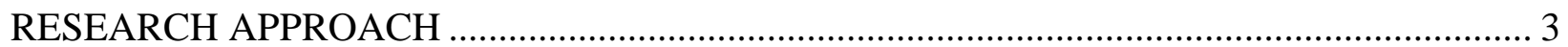

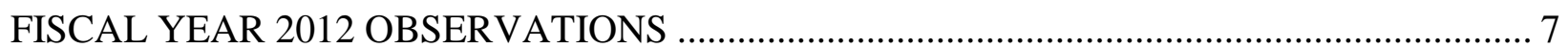

Meteorological Observations ............................................................................................ 7

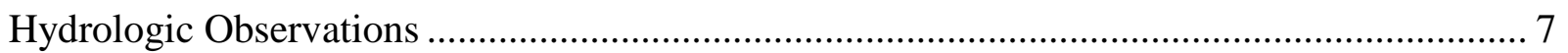

Dust Transport Observations ............................................................................................... 10

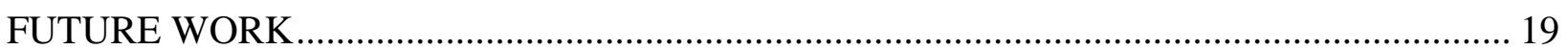

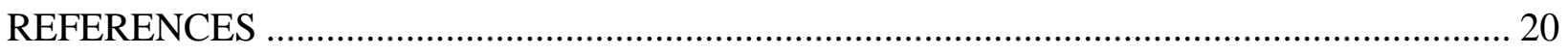

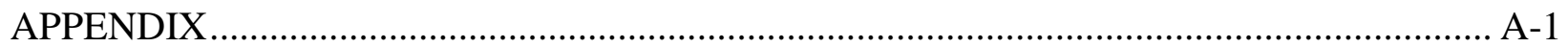

\section{LIST OF FIGURES}

1. Americium-241 detections in Plutonium Valley suggest migration of radionuclidecontaminated soils along channels conveying runoff away from the Corrective Action Sites. Markers numbered 1 through 4 identify the four Project 56 ground zero sites; items 5 and 6 identify plums in channels draining the ground zero areas; and item 7 designates an isolated low activity spot (after Colton [1999] Figure 5). ........................... 2

2. Approximate locations of the meteorological stations and ISCO installation in Plutonium Valley, Nevada. ............................................................................................. 4

3. The meteorological stations in Plutonium Valley were installed to measure precipitation, wind, and other meteorological parameters downwind of the Contmination Area during the dominant south wind in summer (top) and dominant north wind in winter (bottom) . ...................................................................................... 5

4. The ISCO sampler (inside the orange job box) is triggered when the pressure transducer (yellow cable in the stilling well) detects runoff. The ultrasonic depth sensor (on the left, hanging from the pole) measures flow depth. Detection of runoff and flow depth data are relayed by radio signal to the south meteorological station and then by GOES satellite to the Western Regional Climate Center........................................ 6

5. Soil moisture (volumetric water content) observations show changes that reflect precipitation events.

6. The pressure transducer at the Plutonium Valley ISCO station indicated positive pressure on several occasions but none were associate with recorded precipitation events. 
7. The sonic sensor reports the height of the reflection surface above the defined "zero" surface. Early December, late March, and mid-July reflection surface spikes in appear to be approximately coincident with measured precipitation events; other spikes in the reflection surface height are erroneous values.

8. Wind roses representing average and maximum hourly wind conditions at the southern (\#1) and northern (\#2) meteorological stations in Plutonium Valley indicate different patterns at the two stations...

9. Wind roses for the Plutonium Valley meteorological stations show more similarity for wind speeds in excess of $15 \mathrm{mph}$.

10. Rose diagrams illustrating the distribution of PM10 particles for the average hourly and average hourly greater than $15 \mathrm{mph}$ wind conditions.

11. Comparison of wind speed and PM10 correlations reveals similar patterns at both the southern and northern Plutonium Valley meteorological stations.

12. Observed hourly wind speed and PM10 values of a dust event in late November 2011 illustrate the complicated relationship between wind and dust concentration.

\section{LIST OF TABLES}

1. Universal Transverse Mercator (Zone 11 South) coordinates for equipment installed for the Plutonium Valley runoff transport study.

2. Average monthly and period of record observations reflecting meteorological conditions at the Plutonium Valley \#1 station, NNSS.

3. Average monthly and period of record observations reflecting meteorological conditions at the Plutonium Valley \#2 station, NNSS.

4. The duration of winds of a particular speed decrease and the associated PM10 concentration increase as the wind speed increases.

\section{LIST OF ACRONYMS}

$\begin{array}{ll}\text { Am-241 } & \text { Americium-241 } \\ \text { CA } & \text { Contamination Area } \\ \text { CAS } & \text { Corrective Action Site } \\ \text { CAU } & \text { Corrective Action Unit } \\ \text { DRI } & \text { Desert Research Institute } \\ \text { DOE } & \text { Department of Energy } \\ \text { GOES } & \text { Geostationary Operational Environmental Satellite } \\ \text { NNSS } & \text { Nevada National Security Site } \\ \text { RCT } & \text { Radiological Control Technician } \\ \text { WRCC } & \text { Western Regional Climate Center }\end{array}$




\section{INTRODUCTION}

The U.S. Department of Energy (DOE) National Nuclear Security Administration (NNSA), Nevada Site Office (NSO), Environmental Restoration Soils Activity has authorized the Desert Research Institute (DRI) to conduct field assessments of potential sediment transport of contaminated soil from Corrective Action Unit (CAU) 366, Area 11 Plutonium Valley Dispersion Sites Contamination Area (CA) during precipitation runoff events.

Field measurements at the T-4 Atmospheric Test Site (CAU 370) suggest that radionuclide-contaminated soils may have migrated along a shallow ephemeral drainage that traverses the site (NNSA/NSO, 2009). (It is not entirely clear how contaminated soils got into their present location at the T-4 Site, but flow to the channel has been redirected and the contamination does not appear to be migrating at present.) Aerial surveys in selected portions of the Nevada National Security Site (NNSS) also suggest that radionuclide-contaminated soils may be migrating along ephemeral channels in Areas 3, 8, 11, 18, and 25 (Colton, 1999). In Area 11, several low-level airborne surveys of the Plutonium Valley Dispersion Sites (CAU 366) show plumes of Americium 241 (Am-241) extending along ephemeral channels (Figure 1, marker numbers 5 and 6) below Corrective Action Site (CAS) 11-23-03 (marker number 3) and CAS 11-23-04 (marker number 4) (Colton, 1999).

Plutonium Valley in Area 11 of the NNSS was selected for the study because of the aerial survey evidence suggesting downstream transport of radionuclide-contaminated soil. The aerial survey (Figure 1) shows a well defined finger of elevated radioactivity (marker number 5) extending to the southwest from the southernmost detonation site (marker number 4). This finger of contamination overlies a drainage channel mapped on the topographic base map used for presentation of the survey data suggesting surface runoff as a likely cause of the contaminated area. Additionally, instrumenting sites strongly suspected of conveying soil from areas of surface contamination offers the most efficient means to confirm that surface runoff may transport radioactive contamination as a result of ambient precipitation/runoff events.

Closure plans being developed for the CAUs on the NNSS may include post-closure monitoring for possible release of radioactive contaminants. Determining the potential for transport of radionuclide-contaminated soils under ambient meteorological conditions will facilitate an appropriate closure design and post-closure monitoring program.

\section{BACKGROUND}

Plutonium Valley is located east of Yucca Flat dry lake in Area 11 of the NNSS in southeastern Nye County, Nevada. Project 56, which consisted of a series of four nuclear device safety tests, was conducted in the valley in 1955 and 1956. The safety tests were performed at test beds 11a through 11d (Figure 1, marker numbers 1 through 4 ) which are aligned north to south in the valley; these test beds have been designated CASs 11-23-01, 11-23-02, 11-23-03, and 11-23-04, respectively, within CAU 366. In addition, two contaminated waste disposal sites, CAS 11-08-01 and 11-08-02, are also included within CAU 366. The test conducted at test bed 11d, (Figure 1, number 4) (CAS 11-23-04), the southernmost test bed, resulted in extensive alpha contamination on the ground surface (B. Bailey, written communication; Oct 12, 2010) surrounding ground zero. Aerial surveys (Colton, 1999) detected high concentrations of Americium-241 (Am-241) around the three southern test beds (Figure 1, marker numbers 2 through 4) and a significant plume of Am-241 distributed in a north-northeast direction from the 


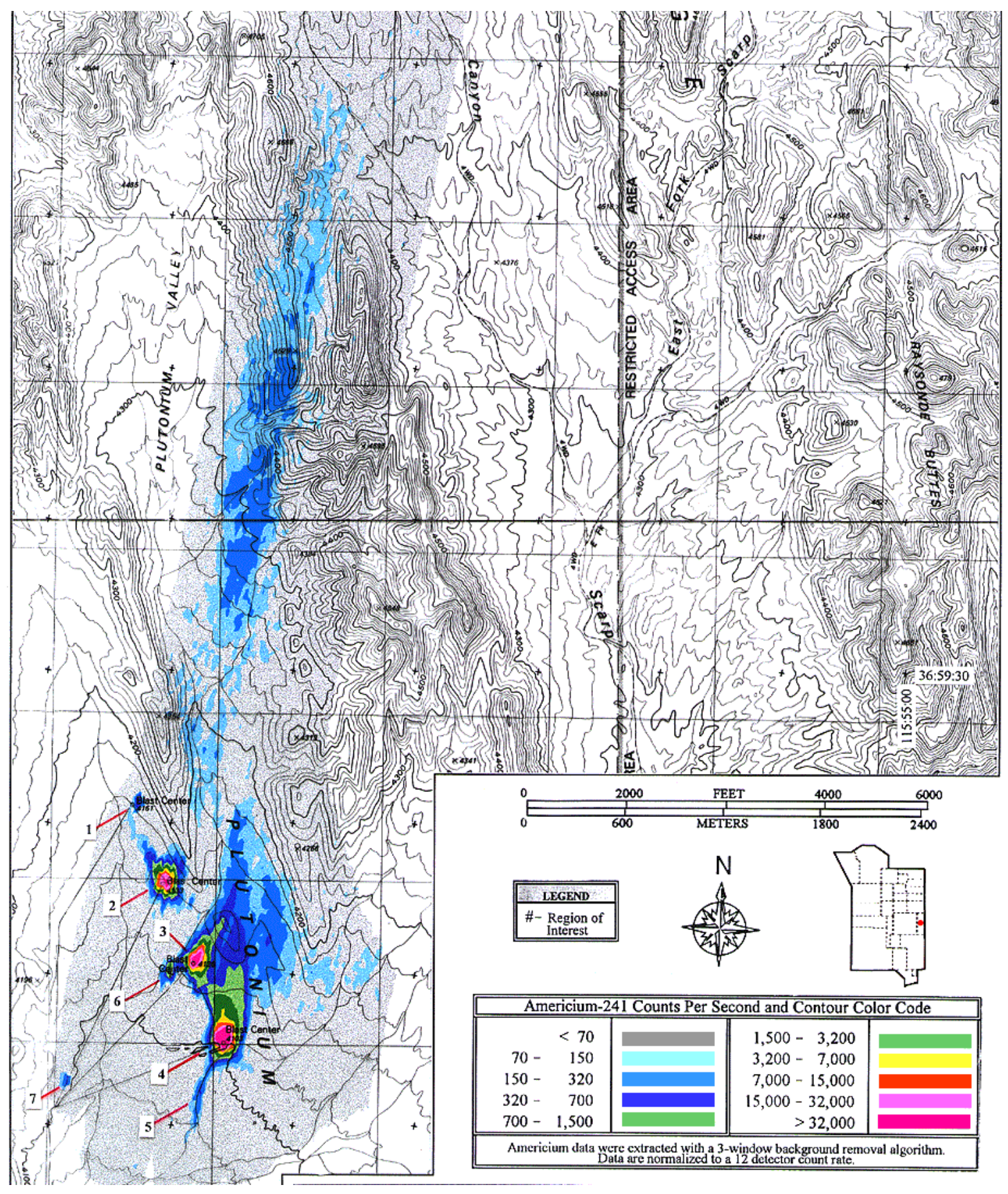

Figure 1. Americium-241 detections in Plutonium Valley suggest migration of radionuclidecontaminated soils along channels conveying runoff away from the Corrective Action Sites. Markers numbered 1 through 4 identify the four Project 56 ground zero sites; items 5 and 6 identify plums in channels draining the ground zero areas; and item 7 designates an isolated low activity spot (after Colton [1999] Figure 5). 
southernmost two test locations (Figure 1, marker numbers 3 and 4). These surveys also showed Am-241 concentrations above background in a channel that conveys runoff from the southernmost test bed (CAS 11-23-04) out of the valley to Yucca Flat dry lake (Figure 1, number 5).

\section{RESEARCH APPROACH}

The presence of radionuclide-contaminated soils in a channel that traverses the southernmost CAS in the Plutonium Valley CA suggests that radionuclide-contaminated soil has been transported in the past during runoff events. Various studies (Colton, 1999; Shinn et al., 1993) also have indicated that radionuclide-contaminated soils have migrated by surface water transport in the past, suggesting additional surface movement of contaminated soils is possible in the future.

Desert Research Institute proposed to perform a field scale assessment of meteorological and hydrologic conditions that would potentially lead to transport of radionuclide-contaminated soil from the Plutonium Valley CA. The research plan includes measurement of local meteorological parameters and collection of suspended sediment contained within the flow, as well as sediment transported as bedload along the channel bed during runoff events. The precipitation and runoff data will be used to establish threshold conditions that would likely lead to transport of soil particles, including radionuclide-contaminated soils. Such thresholds will aid establishment of conditions that cause monitoring of drainage channel transport pathways to be implemented under a future closure plan.

Two meteorological stations, instrumented to measure temperature, relative humidity, wind speed, wind direction, soil volumetric-water content, soil temperature, solar radiation, barometric pressure, precipitation, and particulate matter suspended in air, were installed in uncontaminated areas north and south of the Plutonium Valley CA on August 24 and 25, 2011. Figure 2 shows the locations of instrument stations relative to the ground zero sites in Plutonium Valley and Figure 3 shows photographs of the two meteorological stations. Location coordinates for the two meteorological stations are provided in Table 1. The meteorological stations were installed to determine the variation in climatic conditions and predominate seasonal wind directions. Both meteorological stations include Geostationary Operational Environmental Satellite (GOES) data transmission equipment which is used to transmit accumulated meteorological data to the Western Regional Climate Center (WRCC) at the DRI offices in Reno at regularly scheduled intervals. At the WRCC the data is uploaded to a restricted access internet web page available to project personnel.

An ISCO sampler was installed inside the Plutonium Valley CA (Figure 2 and 4) on August 24, 2011 in conjunction with two bedload traps to collect samples of suspended sediment and bedload sediment transported under ambient precipitation runoff events. Coordinates of the ISCO installation are given in Table 1 . This location is approximately 0.4 miles $(0.64 \mathrm{~km})$ downstream of the southernmost test ground zero (CAS 11-08-04) and approximately 0.6 miles $(0.96 \mathrm{~km})$ upstream of the detention basin at the southwest corner of the CA. The ISCO installation includes an ultrasonic depth sensor used to detect the presence and depth of water in the channel, a pressure transducer used to estimate the depth of flow in the channel, the ISCO sampler that pumps water from the channel into collection bottles, and a datalogger that interfaces between these instruments and the south meteorological station. When water is 


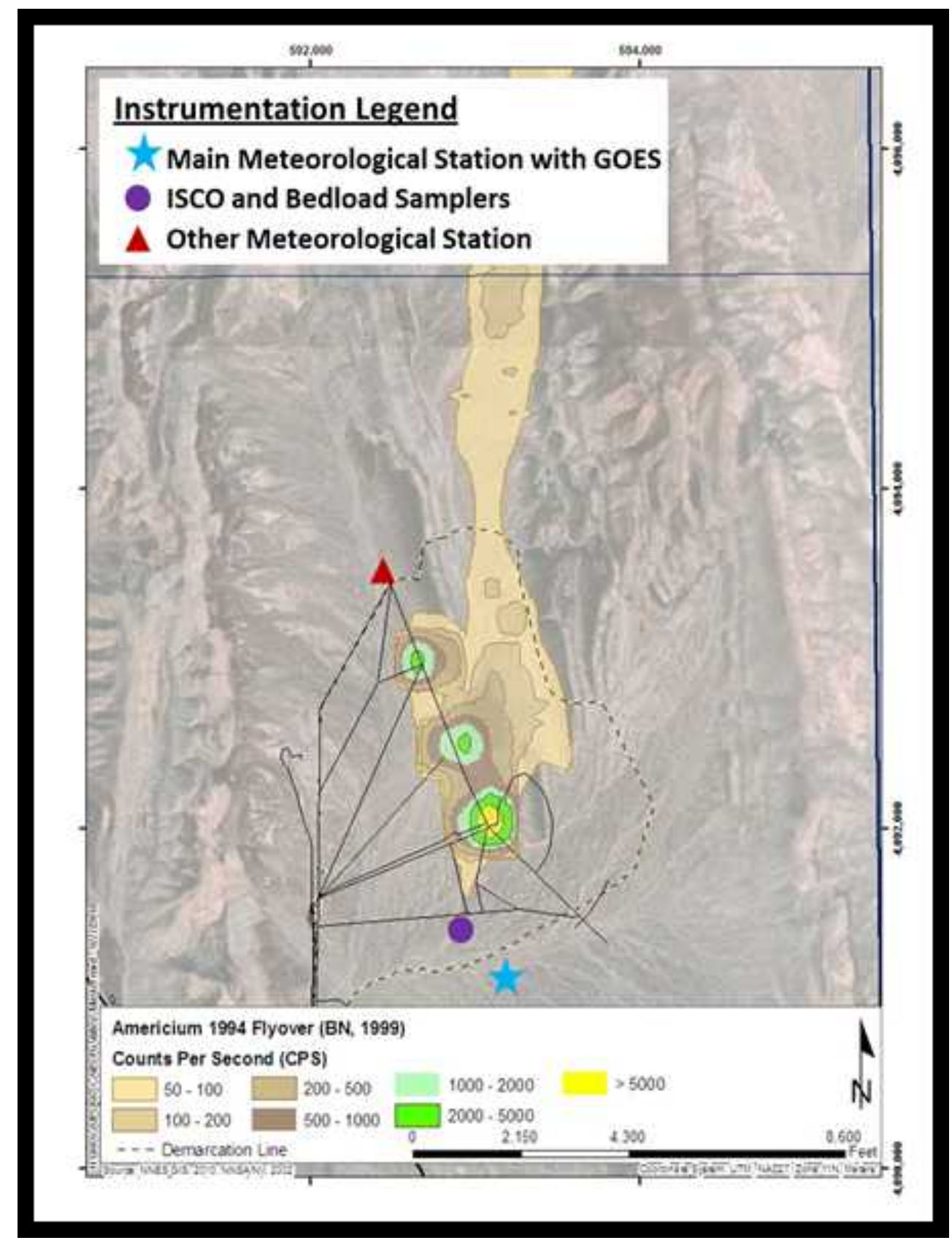

Figure 2. Approximate locations of the meteorological stations and ISCO installation in Plutonium Valley, Nevada.

detected in the channel, the datalogger instructs the ISCO to begin pumping water into the sample bottles. Water is pumped from the channel for a specified period of time and automatically collected in sample bottles inside the ISCO sampler; the bottles rotate through the sampler at specified time intervals to allow samples to be collected from different time periods during the flow event. The sample bottles will be collected and submitted for analysis to determine the suspended soil particle sizes transported in the runoff and the associated radionuclide-contamination. 


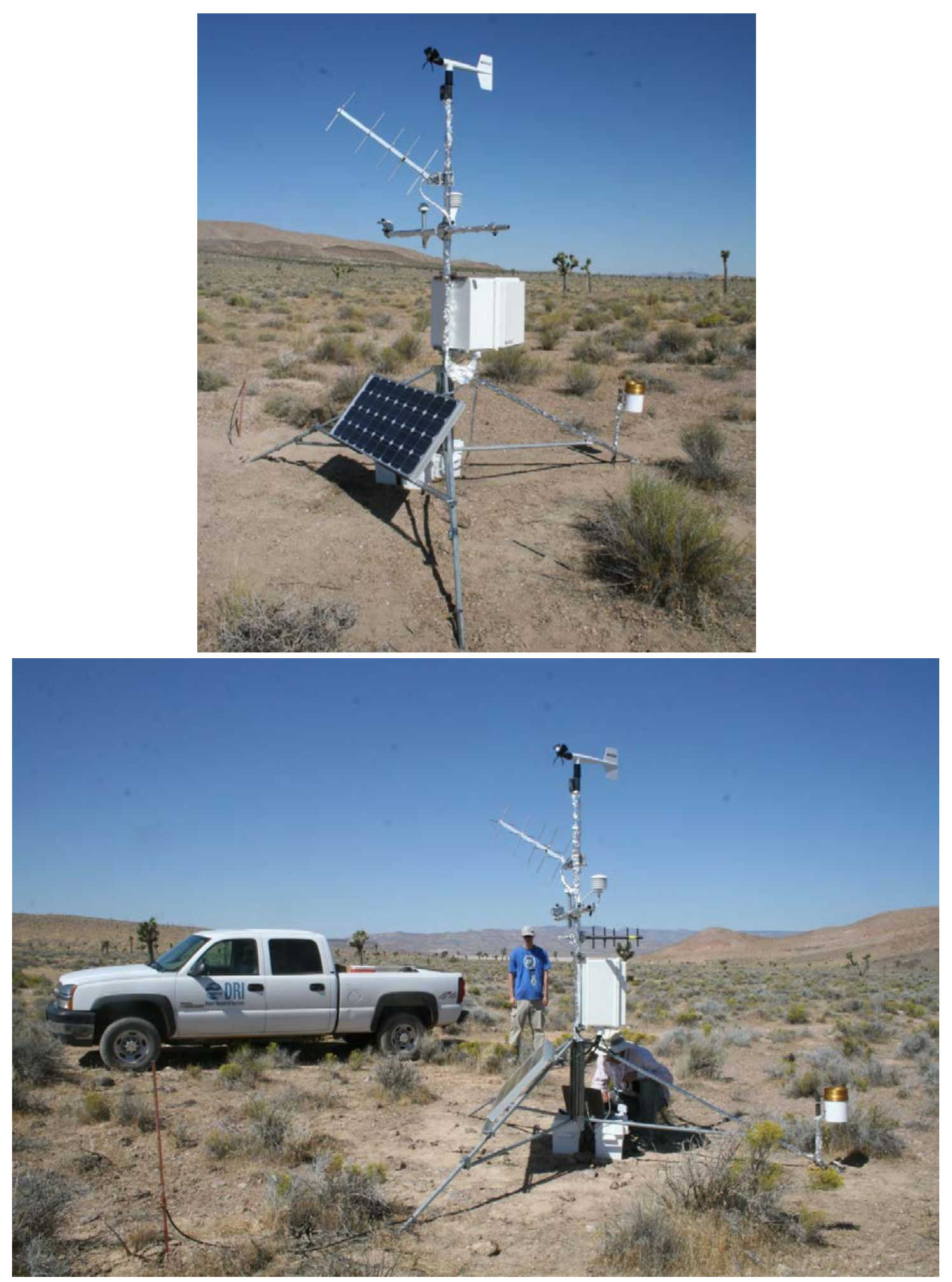

Figure 3. The meteorological stations in Plutonium Valley were installed to measure precipitation, wind, and other meteorological parameters downwind of the Contmination Area during the dominant south wind in summer (top) and dominant north wind in winter (bottom). 
Table 1. Universal Transverse Mercator (Zone 11 South) coordinates for equipment installed for the Plutonium Valley runoff transport study.

\begin{tabular}{lll}
\hline Instrumentation & Easting & Northing \\
\hline North Meteorological Station & 592375 & 4093665 \\
South Meteorological Station & 592739 & 4090724 \\
ISCO Sampler & 592751 & 4091555 \\
\hline
\end{tabular}

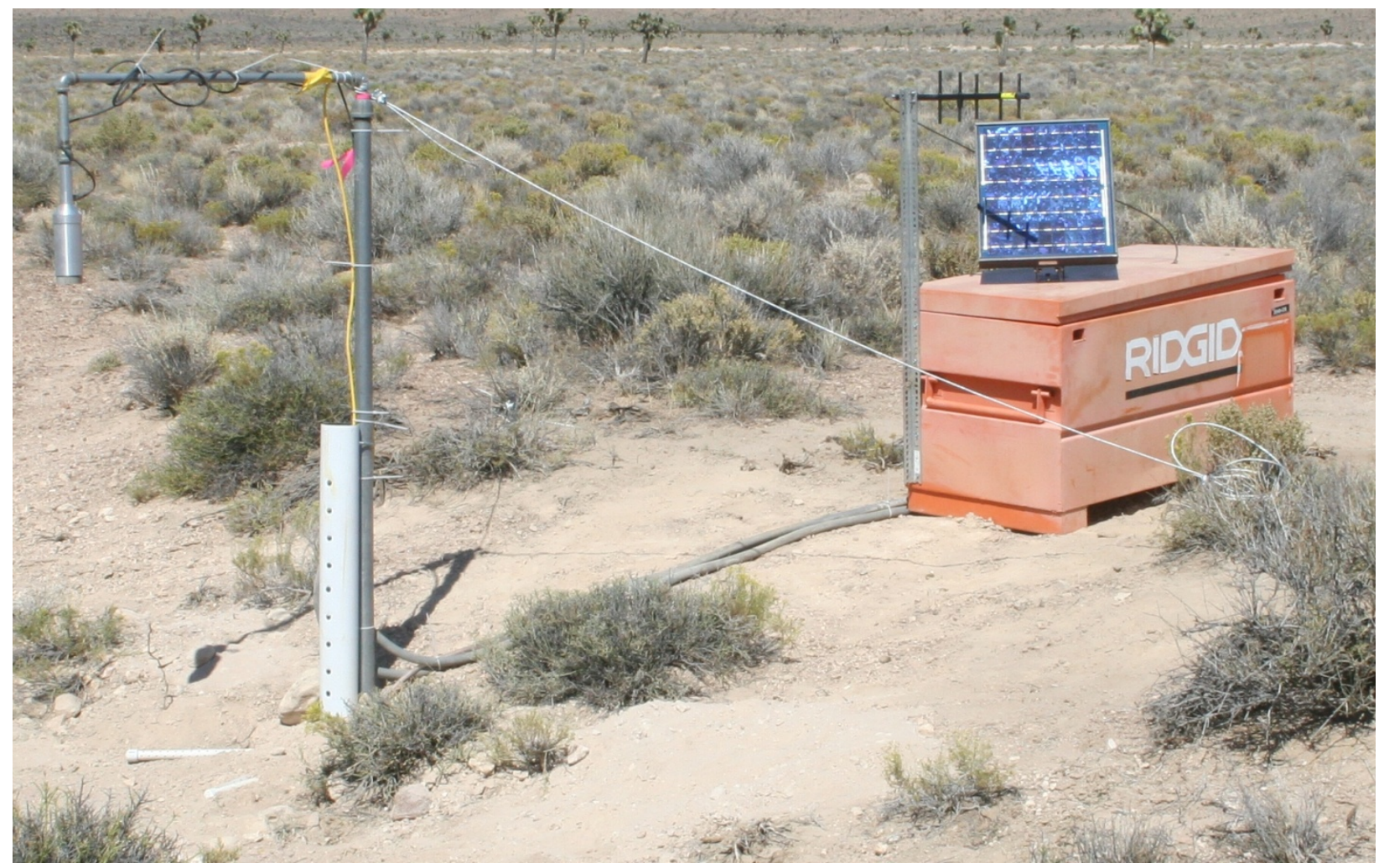

Figure 4. The ISCO sampler (inside the orange job box) is triggered when the pressure transducer (yellow cable in the stilling well) detects runoff. The ultrasonic depth sensor (on the left, hanging from the pole) measures flow depth. Detection of runoff and flow depth data are relayed by radio signal to the south meteorological station and then by GOES satellite to the Western Regional Climate Center.

Every 10 minutes the datalogger at the ISCO station transmits current conditions to the south meteorological station via radio frequency. The signal indicating flow at the ISCO sampler will then be transmitted to the WRCC in the next GOES satellite transmission alerting project personnel to the flow event. Initial meteorological and ISCO data transmissions from the Plutonium Valley sites were received by WRCC August 29, 2011.

Bedload samples will be collected using passive sediment traps. Two bedload traps were set in the channel at appropriate locations and will be left until a flow event has occurred. The 
traps consist of a nylon net attached to an aluminum frame anchored in the channel bed. Bedload material is collected in the net during a flow event and manually transferred to a sample container after the flow event has passed. Retrieval of the suspended and bedload samples will require Radiological Control Technician (RTC) support because entry into the Plutonium Valley CA is required.

\section{FISCAL YEAR 2012 OBSERVATIONS}

Measurements of air temperature, relative humidity, wind speed and direction, soil volumetric-water content, soil temperature, solar radiation, barometric pressure, precipitation, and water depth at the ISCO sampler are collected every three seconds. These values are averaged or totaled, as appropriate, and recorded on the data logger every ten minutes. Because GOES transmission time is limited, the 10-minute data are averaged for each hour before transmission to the WRCC. The 10-minute data are retained on the data logger and downloaded during periodic site visits. The last datalogger download was accomplished on August 1, 2012.

\section{Meteorological Observations}

Ten-minute meteorological data collected from the Plutonium Valley stations through August 1 and the daily meteorological data since August 1 have been summarized in Tables 2 and 3 by month and for the period of record. Daily average values of the meteorological parameters observed at these stations are shown in time series plots presented in Appendices A and B. During the period of record (August 292011 through September 16 2012), the monthly summary data indicates that: (1) the average monthly temperature was warmest in July and August and coldest in December; (2) soil temperature followed a similar pattern; (3) monthly average relative humidity was highest in November 2011 and lowest in June 2012; (4) July and August 2012 had the highest precipitation amounts ( 0.76 in and $1.92 \mathrm{in}$, station \#2); and (5) the average wind speed was greatest in March 2012 and calmest in September 2011.

The Plutonium Valley meteorological stations generally exhibit similar meteorological conditions, although station \#2 is approximately $2.78 \mathrm{~km}(1.73 \mathrm{mi})$ north of and $25 \mathrm{~m}(82 \mathrm{ft})$ higher than station \#1. However, they are sufficiently separated to illustrate the meteorological variability likely to be observed in southwest desert climates. For example, the typical wind direction at station \#1 is from the southeast but from the west-northwest at station \#2; maximum and minimum soil temperatures are slightly more extreme at station \#1; and August precipitation was higher at station \#1 but September precipitation was higher at station \#2 (Tables 2 and 3).

\section{Hydrologic Observations}

Soil moisture is measured at both Plutonium Valley meteorological stations in conjunction with the meteorological parameters. Note that Figure 5 presents the volumetric soil moisture content for both the \#1 and \#2 stations; however, hourly data is presented for station \#1 and 10-minute data is presented for station \#2 and data for the two stations are presented at different scales. At both stations, the soil moisture appears to respond to precipitation events. Volumetric soil moisture at Plutonium Valley station \#1 ranged from about $10 \%$ to $21 \%$. It was driest in early to mid-July 2012 and highest in mid-April 2012 in response to a significant precipitation event. At Plutonium Valley station \#2 the volumetric soil moisture content ranged from 0.05 (5\%) in early December and again in early July to 0.19 (19\%) following a notable precipitation event in mid-April 2012. Generally, soil moisture rose following precipitation events that exceeded 0.02 in. Rainfall of lessor magnitude did not produce a notable change in 
Table 2. Average monthly and period of record observations reflecting meteorological conditions at the Plutonium Valley \#1 station, NNSS.

\begin{tabular}{|c|c|c|c|c|c|c|c|c|c|c|c|c|c|c|c|c|c|}
\hline & $\begin{array}{c}\text { Solar } \\
\text { Radiation }\end{array}$ & $\begin{array}{l}\text { Mean } \\
\text { Wind }\end{array}$ & $\begin{array}{l}\text { Mean } \\
\text { Wind }\end{array}$ & $\begin{array}{c}\text { Maximum } \\
\text { Wind }\end{array}$ & \multicolumn{5}{|c|}{ Average Air Temperature } & Average $S$ & emperat & 4 Inches & \multicolumn{3}{|c|}{ Average Relative Humidity } & $\begin{array}{c}\text { Barometric } \\
\text { Pressure }\end{array}$ & Precipitation \\
\hline Date & ly & $\mathrm{mph}$ & Deg & $\mathrm{mph}$ & \multicolumn{5}{|c|}{$\operatorname{Deg} F$} & \multicolumn{3}{|c|}{$\operatorname{Deg} F$} & \multicolumn{3}{|c|}{$\%$} & in. $\mathrm{Hg}$ & in \\
\hline $\mathrm{mm} / \mathrm{yyyy}$ & Total & Ave. & $\begin{array}{l}\text { Vector } \\
\text { Ave. }\end{array}$ & Max. & Ave. & $\begin{array}{c}\text { Ave. Daily } \\
\text { Max. }\end{array}$ & Max. & $\begin{array}{c}\text { Ave. Daily } \\
\text { Min. }\end{array}$ & Min. & Ave. & Max. & Min. & Ave. & Max. & Min. & Ave. & Total \\
\hline Aug-11 & 3998 & 5.415 & 167.7 & 32.3 & 82.93 & 95.1 & 100.4 & 64.71 & 55.96 & 88.76 & 115.8 & 64.94 & 20.58 & 46.69 & 0.831 & na & 0.01 \\
\hline Sep-11 & 12164 & 4.294 & 133.6 & 49.17 & 71.27 & 88.07 & 94.93 & 52.96 & 46.56 & 76.5 & 110.8 & 54.43 & 29.04 & 94.5 & 1.253 & 17.72 & 0.33 \\
\hline Oct-11 & 11132 & 4.867 & 123.4 & 37.99 & 57.99 & 75.35 & 87.28 & 41.31 & 29.43 & 61.35 & 93.16 & 36.74 & 30.78 & 97.6 & 1.822 & 17.72 & 0.17 \\
\hline Nov-11 & 6566 & 4.586 & 121.9 & 43.33 & 40.44 & 56.93 & 70.14 & 24.82 & 16.27 & 43.69 & 71.73 & 22.29 & 45.47 & 95.9 & 6.483 & 25.06 & 0 \\
\hline Dec-11 & 6266 & 5.735 & 61.66 & 46.47 & 36.08 & 51.79 & 63.41 & 22.81 & 8.888 & 37.12 & 60.6 & 16.05 & 39.95 & 100 & 6.623 & 23.74 & 0.18 \\
\hline Jan-12 & 7851 & 4.73 & 111.5 & 41.5 & 38.96 & 56.21 & 68.32 & 24.03 & 7.718 & 39.38 & 64.69 & 18.18 & 33.6 & 100 & 0.366 & 21.53 & 0.09 \\
\hline Feb-12 & 8630 & 5.323 & 78.52 & 35.66 & 40.88 & 54.85 & 67.33 & 26.39 & 17.13 & 43.41 & 72.12 & 23.96 & 42.85 & 99.3 & 0.745 & 19.96 & 0.12 \\
\hline Mar-12 & 12351 & 7.514 & 162.5 & 47.64 & 47.91 & 62.29 & 74.08 & 31.79 & 21.6 & 51.66 & 81.34 & 28.85 & 34.95 & 93.2 & 3.398 & 17.98 & 0.44 \\
\hline Apr-12 & 15400 & 6.643 & 157.6 & 44.57 & 57.13 & 70.95 & 90.09 & 40.24 & 22.33 & 63.07 & 100.8 & 33.63 & 29.31 & 99.6 & 0.432 & 17.89 & 0.6384 \\
\hline May-12 & 19009 & 7.159 & 165.7 & 49.61 & 68.4 & 82.34 & 94.8 & 49.91 & 34.61 & 76.19 & 115.1 & 45.79 & 14.73 & 64.81 & 1.175 & 17.75 & 0 \\
\hline Jun-12 & 19066 & 7.475 & 169.5 & 38.87 & 76.43 & 91.15 & 97.61 & 55.38 & 46.65 & 84.35 & 120.7 & 55.87 & 11.3 & 39.63 & 1.377 & 17.72 & 0 \\
\hline Jul-12 & 15793 & 5.553 & 159 & 34.05 & 78.76 & 93.39 & 105.2 & 59.27 & 49.33 & 85.53 & 125.3 & 61.72 & 28.23 & 96.9 & 1.394 & 17.72 & 0.79 \\
\hline Aug-12 & 15146 & 5.135 & 161.5 & 33.46 & 81.17 & 95 & 102.8 & 64.82 & 54.28 & 86.68 & 117.1 & 61.99 & 36.95 & 98.3 & 7.863 & 19.95 & 1.36 \\
\hline Sep-12 & 10922 & 4.336 & 146.7 & 28.79 & 73.38 & 88.25 & 94.46 & 56.17 & 48.38 & 77.11 & 106.4 & 55 & 31.4 & 93.2 & 3.084 & 25.91 & 1.22 \\
\hline $\begin{array}{l}\text { Record } \\
\text { Average }\end{array}$ & 11735.29 & 5.63 & 137.20 & 40.24 & 60.84 & 75.83 & 86.49 & 43.90 & 32.80 & 65.34 & 96.83 & 41.39 & 30.65 & 87.12 & 2.63 & 20.05 & 0.38 \\
\hline
\end{tabular}


Table 3. Average monthly and period of record observations reflecting meteorological conditions at the Plutonium Valley \#2 station, NNSS.

\begin{tabular}{|c|c|c|c|c|c|c|c|c|c|c|c|c|c|c|c|c|c|}
\hline & $\begin{array}{c}\text { Solar } \\
\text { Radiation }\end{array}$ & $\begin{array}{l}\text { Mean } \\
\text { Wind } \\
\text { Speed }\end{array}$ & $\begin{array}{c}\text { Mean } \\
\text { Wind } \\
\text { Direction }\end{array}$ & $\begin{array}{c}\text { Maximum } \\
\text { Wind } \\
\text { Gust }\end{array}$ & \multicolumn{5}{|c|}{ Average Air Temperature } & Average & Tempera & 4 Inches & \multicolumn{3}{|c|}{ Average Relative Humidity } & $\begin{array}{c}\text { Barometric } \\
\text { Pressure }\end{array}$ & Precipitation \\
\hline Date & ly & $\mathrm{mph}$ & Deg & $\mathrm{mph}$ & \multicolumn{5}{|c|}{ DegF } & \multicolumn{3}{|c|}{ DegF } & \multicolumn{3}{|c|}{$\%$} & in. $\mathrm{Hg}$ & in \\
\hline $\mathrm{mm} / \mathrm{yyyy}$ & Total & Ave. & $\begin{array}{l}\text { Vector } \\
\text { Ave. }\end{array}$ & Max. & Ave. & $\begin{array}{c}\text { Ave. Daily } \\
\text { Max. }\end{array}$ & Max. & $\begin{array}{c}\text { Ave. Daily } \\
\text { Min. }\end{array}$ & Min. & Ave. & Max. & Min. & Ave. & Max. & Min. & Ave. & Total \\
\hline Aug-11 & 4073 & 6.215 & 216.7 & 34.2 & 83.05 & 98.01 & 100.1 & 63.9 & 52.79 & 89.04 & 108.3 & 68.34 & 19.3 & 46.19 & 0.577 & 18.02 & 0.07 \\
\hline Sep-11 & 13695 & 4.35 & 335.9 & 44.35 & 71.75 & 88.16 & 95.09 & 52.85 & 44.84 & 77.29 & 103.3 & 57.11 & 27.22 & 94.8 & 1.303 & 23.29 & 0.32 \\
\hline Oct-11 & 12142 & 5.106 & 336.3 & 36.75 & 58.33 & 75.49 & 86.97 & 39.9 & 25.22 & 62.54 & 88.99 & 40.37 & 29.65 & 98.1 & 1.29 & 26.55 & 0.17 \\
\hline Nov-11 & 8305 & 4.736 & 332.7 & 41.65 & 41.26 & 57.17 & 71.04 & 24.32 & 12.88 & 45.29 & 66.42 & 28.88 & 43.94 & 98.5 & 5.676 & 26.57 & 0 \\
\hline Dec-11 & 7567 & 6.085 & 343.2 & 44.72 & 36.76 & 51.99 & 63.95 & 21.05 & 8.924 & 38.01 & 52.95 & 23.68 & 37.85 & 100 & 5.505 & 26.64 & 0.17 \\
\hline Jan-12 & 8530 & 4.91 & 335.9 & 40.7 & 39.89 & 56.38 & 69.58 & 22.73 & 6.53 & 39.99 & 56.35 & 23.1 & 31.36 & 100 & 0.314 & 26.66 & 0.06 \\
\hline Feb-12 & 9939 & 5.488 & 337.7 & 33.03 & 41.07 & 54.84 & 68.09 & 25.28 & 16.39 & 43.76 & 64.51 & 28.14 & 42.12 & 99.4 & 0.521 & 26.52 & 0.13 \\
\hline Mar-12 & 13079 & 7.242 & 236.9 & 47.2 & 48.14 & 62.85 & 75.25 & 30.57 & 18.15 & 51.88 & 75.72 & 31.5 & 34.37 & 96.4 & 2.464 & 26.46 & 0.24 \\
\hline Apr-12 & 16667 & 6.564 & 284.2 & 46.25 & 56.95 & 70.83 & 89.82 & 39.55 & 25.51 & 63.58 & 95.5 & 38.07 & 29.18 & 99.8 & 0.012 & 26.47 & 0.62 \\
\hline May-12 & 21119 & 7.05 & 294.6 & 51.22 & 68.48 & 82.45 & 94.91 & 48.57 & 33.18 & 77.57 & 107.1 & 51.87 & 14.43 & 67 & 0.591 & 26.42 & 0 \\
\hline Jun-12 & 21532 & 7.228 & 219.4 & 42.52 & 75.97 & 91.21 & 97.68 & 54.23 & 46.33 & 85.48 & 112.6 & 62.46 & 11.21 & 41.61 & 1.027 & 26.4 & 0 \\
\hline Jul-12 & 19427 & 5.434 & 202.1 & 33.9 & 78.67 & 93.59 & 105.2 & 58.93 & 48.74 & 87.4 & 117.3 & 65.28 & 27.85 & 96.4 & 1.28 & 26.52 & 0.76 \\
\hline Aug-12 & 17293 & 5.187 & 258.7 & 33.03 & 80.76 & 94.12 & 101.8 & 65.71 & 56.57 & 87.77 & 112.4 & 65.73 & 36.92 & 96.1 & 7.87 & 26.52 & 1.92 \\
\hline Sep-12 & 10978 & 4.439 & 321.7 & 33.32 & 73.51 & 87.46 & 93.61 & 58.13 & 49.96 & 79.55 & 102.5 & 62.67 & 27.88 & 87 & 3.415 & 26.59 & 0.21 \\
\hline $\begin{array}{l}\text { Record } \\
\text { Average }\end{array}$ & 13167.57 & 5.72 & 289.71 & 40.20 & 61.04 & 76.04 & 86.65 & 43.27 & 31.86 & 66.37 & 90.28 & 46.23 & 29.52 & 87.24 & 2.27 & 25.69 & 0.33 \\
\hline
\end{tabular}


the measured moisture content. However, antecedent soil moisture conditions also played a role causing small precipitation events falling on already damp soil to produce a noticeable change in soil moisture content.

A pressure transducer and a sonic distance sensor were installed to detect the presence of water in the channel at Plutonium Valley and to trigger the ISCO sampler to begin collecting when water was present. Figure 6 presents the pressure variation recorded by the transducer. The original transducer was replaced in mid-April; the instrument exchange and seasonal conditions resulted in the increased range of high frequency pressure fluctuations after mid-April. The pressure transducer record implies that water was present at the transducer on six or seven occasions beginning in mid-May; however, none of these positive pressure observations are clearly associated with precipitation events. Figure 7 shows the maximum elevation of the sonic sensor reflection surface. There are several spikes in the record that might indicate water (or some other object) in the channel; only three of the spikes, early December, late March, and midJuly appear to be associated with measured precipitation events. The other spikes appear to be erroneous values.

The early December and late March sonic sensor spikes failed to trigger the ISCO sampler. Each time the ISCO is triggered to collect water samples it must be reset manually before it will enter a subsequent collection sequence. Thus, because the mid-July spike occurred between a prior activation and re-setting of the ISCO there was no opportunity for the equipment to collect a sample.

No water samples were collected by the ISCO. Thus, either the pressure transducer and sonic sensor did not efficiently trigger the ISCO or there was insufficient water in the channel to collect. Inspection of the channel during a site visit on 30 July 2012 revealed no evidence of flow adequate for the sample collection.

\section{Dust Transport Observations}

Radioactive material tends to bind to smaller soil particles; therefore, it is important to assess the conditions of aeolian transport. Wind is a major driving mechanism for the aeolian soil migration in the desert southwest and as such it is critical to monitor wind in conjunction with real-time particulate matter (PM) concentration to determine when large amounts of dust and fine particles are suspend due to wind conditions. Wind needs to exceed a certain threshold below which very little dust re-suspension occurs but this threshold is dependent on many variables such as soil crust strength, extent of soil disturbance, soil moisture, and vegetation cover to name few.

Even though the two stations are relatively near each other (2.8 km (1.7 miles) apart) the overall appearance of wind roses is somewhat different. This is mainly caused by the relatively low wind speeds that occur frequently in the area and are highly influenced by the local geography. Figure 8 shows the maximum hourly wind speeds for both stations for the period from late August of 2011 to late August of 2012 to indicate how maximum hourly winds (based on measured $5 \mathrm{sec}$ wind gusts) are significantly higher than the average wind speed. It is important to note that for a significant dust event sustained high winds are required as illustrated in the analysis later in the report. 


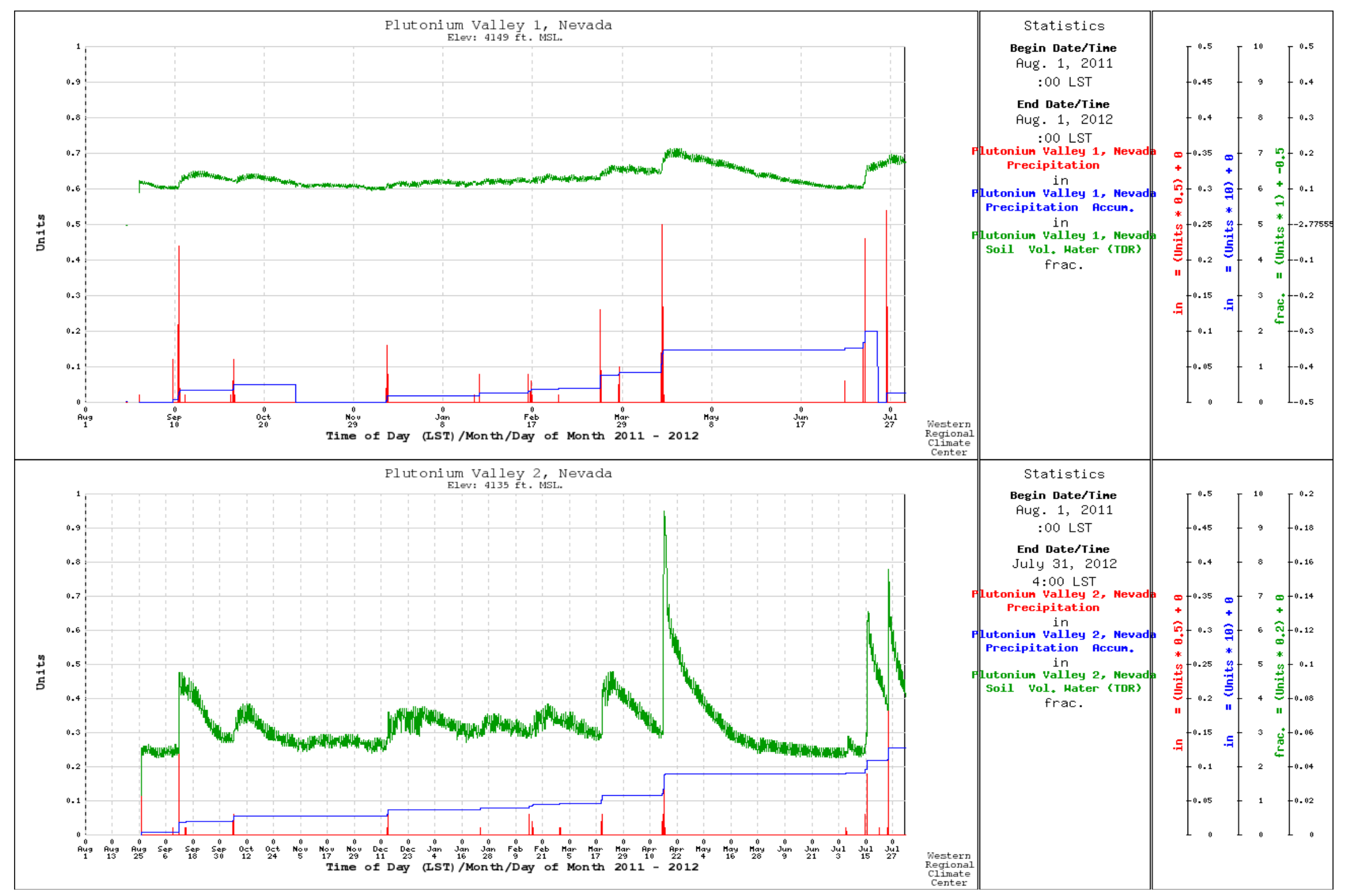

Figure 5. Soil moisture (volumetric water content) observations show changes that reflect precipitation events. 


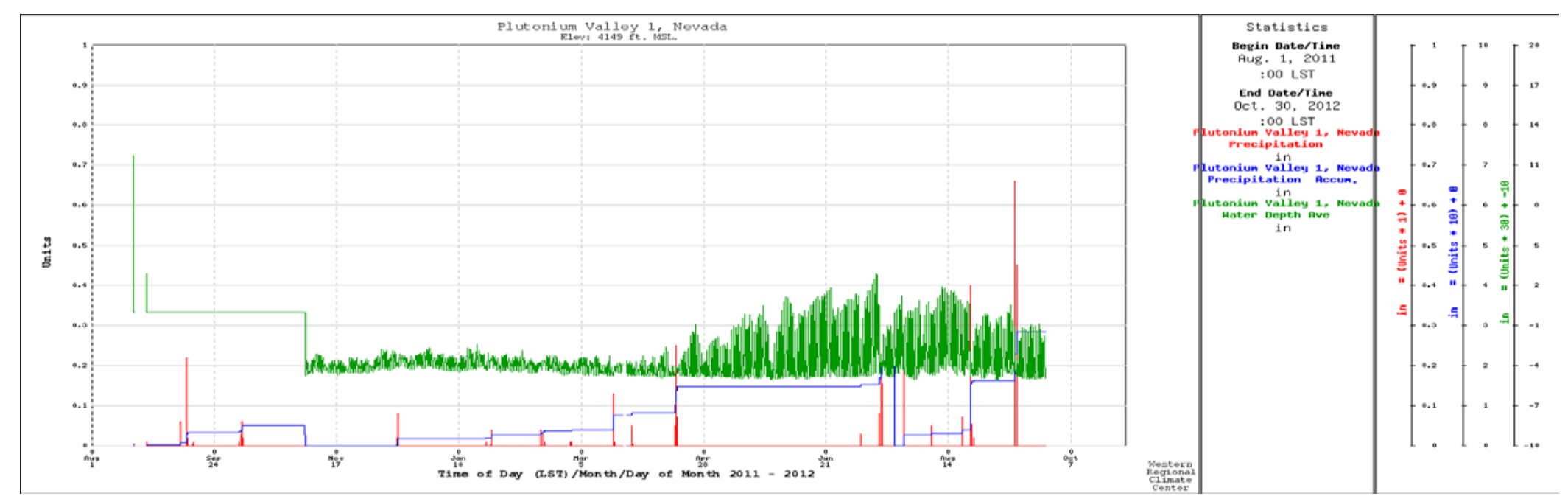

Figure 6. The pressure transducer at the Plutonium Valley ISCO station indicated positive pressure on several occasions but none were associate with recorded precipitation events.

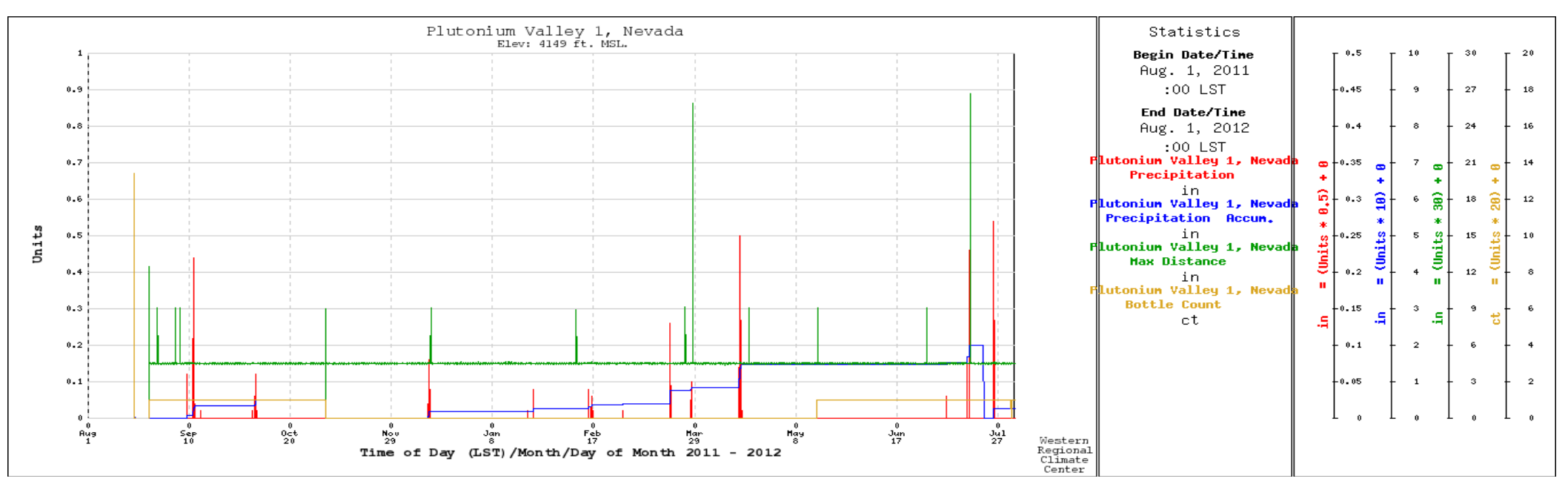

Figure 7. The sonic sensor reports the height of the reflection surface above the defined "zero” surface. Early December, late March, and mid-July reflection surface spikes in appear to be approximately coincident with measured precipitation events; other spikes in the reflection surface height are erroneous values. 
Pu Valley Southern Met Station Average Hourly WS

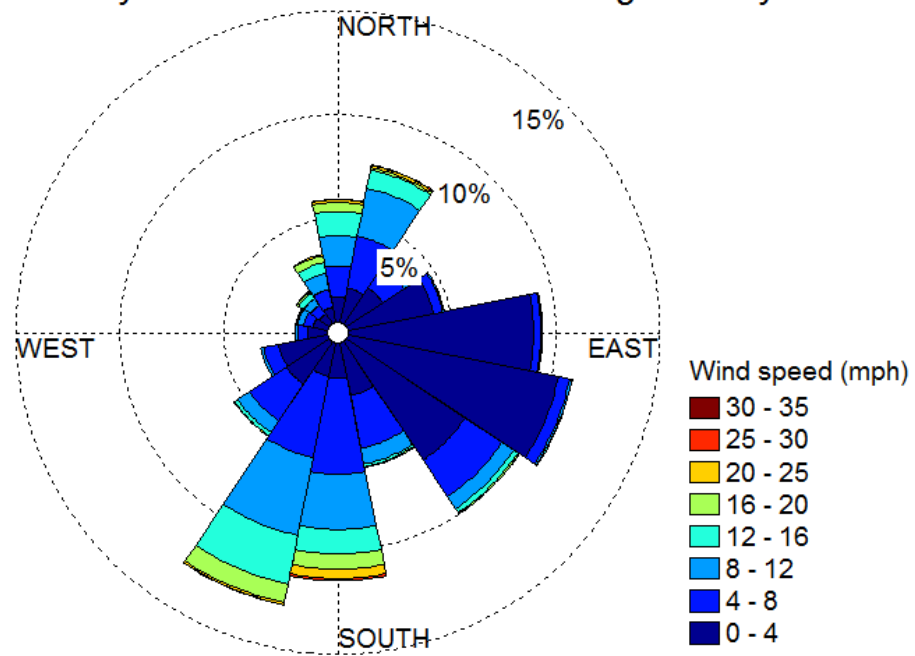

Pu Valley Southern Met Station Max Hourly WS

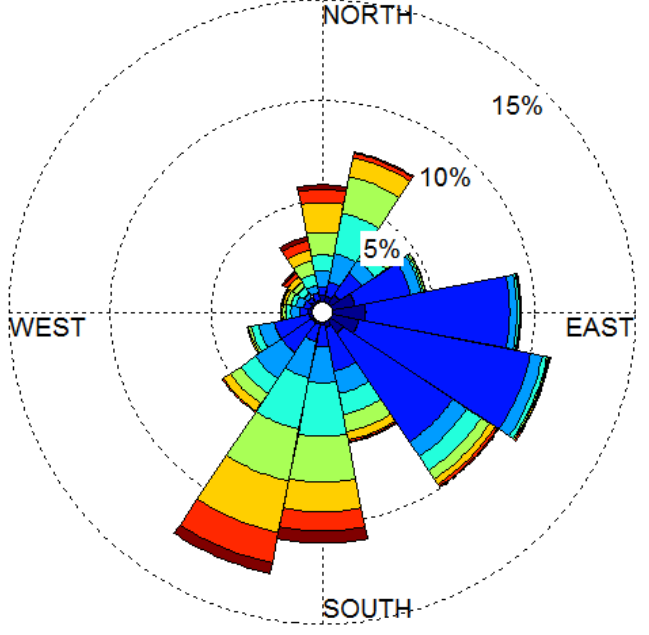

Wind speed (mph

-30-35

$\square$
$\square-30$

$\square 16-20$

$\square 12-16$

$\square 8-12$

$4-8$

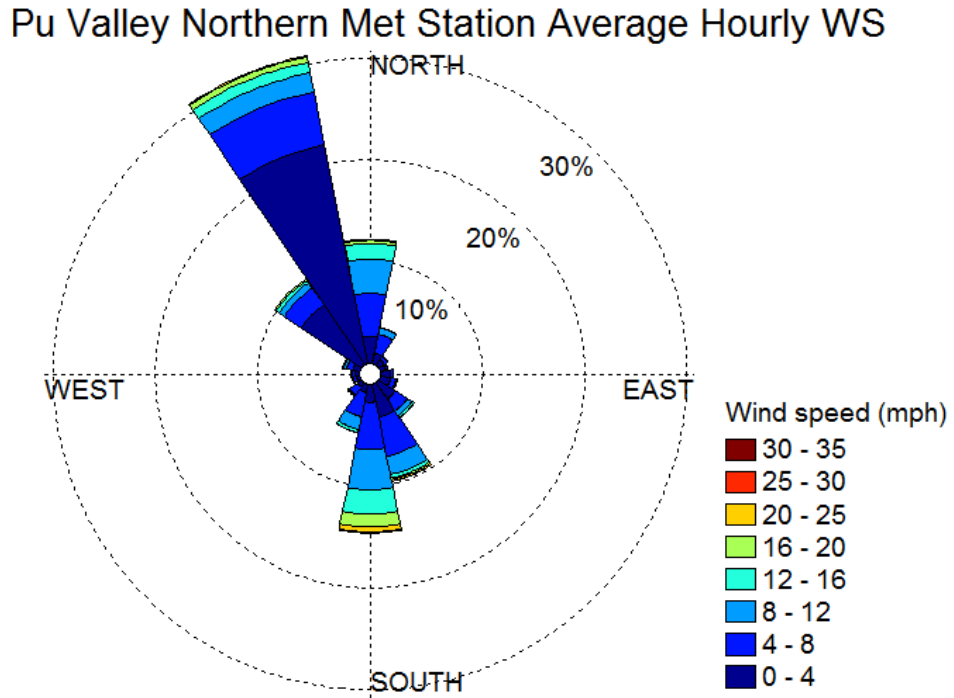

Pu Valley Northern Met Station Max Hourly WS

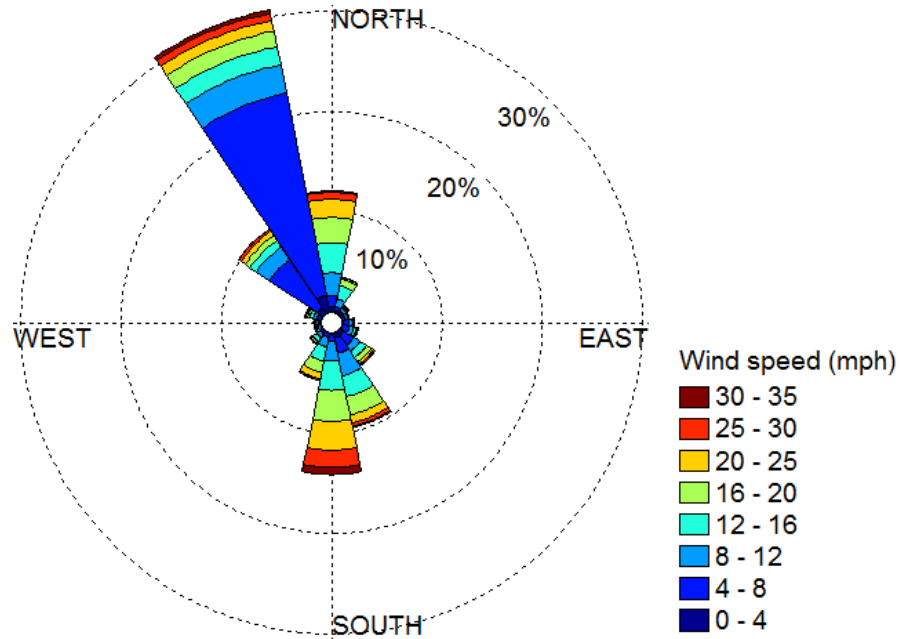

Figure 8. Wind roses representing average and maximum hourly wind conditions at the southern (\#1) and northern (\#2) meteorological stations in Plutonium Valley indicate different patterns at the two stations. 
Pu Valley Southern Met Station Average Hourly WS $>15 \mathrm{mph}$

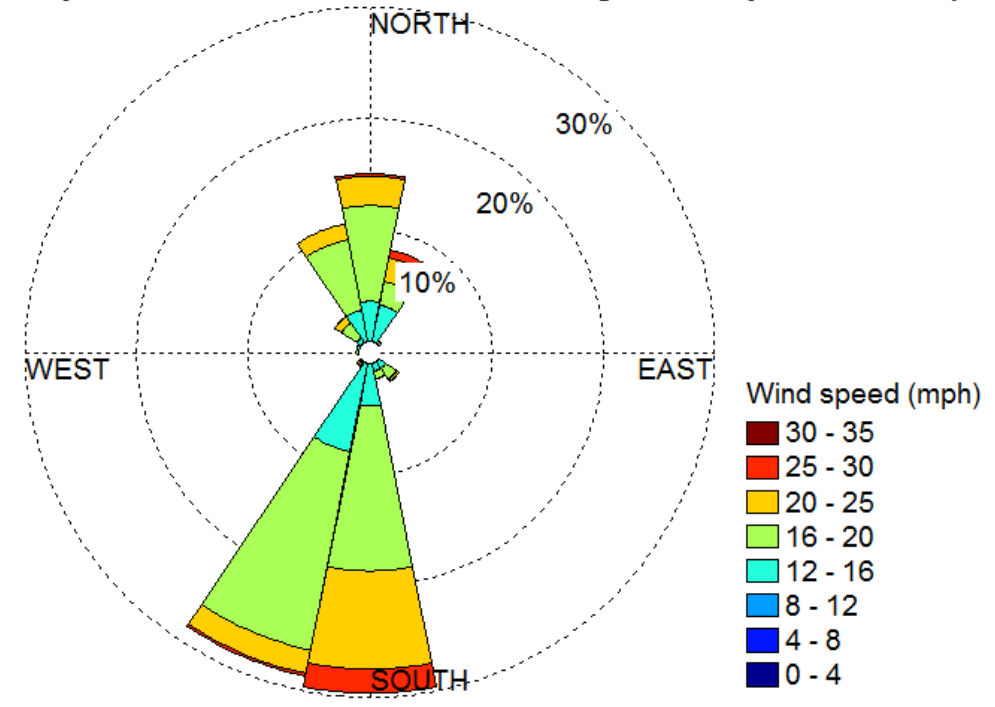

Pu Valley Northern Met Station Average Hourly WS $>15 \mathrm{mph}$

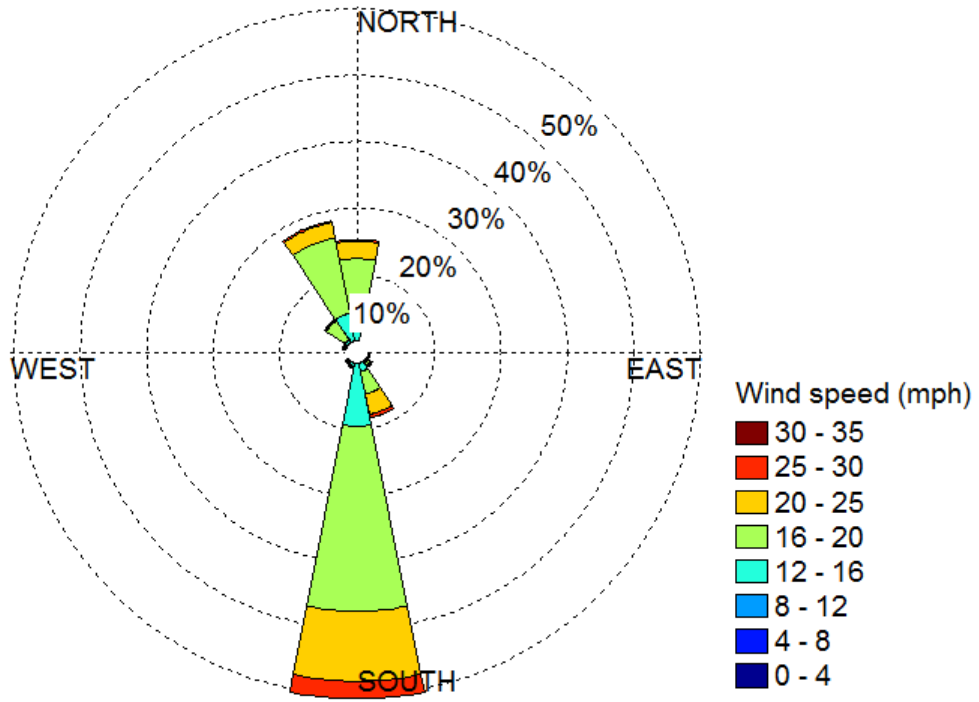

Figure 9. Wind roses for the Plutonium Valley meteorological stations show more similarity for wind speeds in excess of $15 \mathrm{mph}$. 
Wind roses in Figure 8 show the wind data for the southern station illustrate that calm winds below $4 \mathrm{mph}$ occur over significant periods of time and generally occur from all directions except from the West. Note also that wind speeds above $15 \mathrm{mph}$ occur mainly in the north-south direction. Wind data at the north metrological station is more consistent in the north-south direction; this is also true for winds above $15 \mathrm{mph}$ (Figure 9). It is generally true for both stations that the strong winds above $15 \mathrm{mph}$ are more frequent from the south and also higher in magnitude on average than they are form the north.

Generally speaking winds above 15 mph result in elevated PM10 (particulate matter of aerodynamic radius of less than 10 micro meters) concentration in the air. PM10 is an indicator of small size particle that are suspended in air and can be easily inhaled in the human respiratory system. MetOne Particle Profilers (Model 212) are located at both meteorological stations to monitor air borne particle sizes between 0.5-10 um (micro meters) in aerodynamic diameter. Particle counts for eight size ranges between 0.5-10 um are reported every minute and are subsequently averaged and recorded every 10 minutes. The particle counts are converted to a PM10 mass concentration in $\mathrm{ug} / \mathrm{m}^{3}$ (micro grams per meter cube). Figure 10 illustrates the PM10-rose which is very similar to the wind rose but instead of wind seed it conveys information about the average PM10 concentration based on the wind direction. The PM10 roses illustrate the relationship between wind speed and PM10 concentration for a given location. From these figures we can determine if high wind speed from a certain direction corresponds to high PM10 concentration or if there is PM10 transport coming from some more distant source. It is worth noting that at the south station high PM10 concentrations occur in the north-south direction which is consistent with strong local winds indicating a nearby source but also notice that PM10 from the east is high and associated with winds which are generally low indicating a distant PM10 source. In the case of the Plutonium Valley monitoring, the PM10 transport from the nearby source area which may transport contamination are of greatest concern. Data for the northern metrological station indicates that PM10 transport follows the local winds. It is important to note that for 80 to $85 \%$ of the time PM10 concentrations are fairly low (below 10 $\mathrm{ug} / \mathrm{m}^{3}$ ) which indicates stable conditions and comes close to natural background levels for PM10 concentration.

Figure 10 also illustrates the PM10 concentrations associated with wind speeds in excess of $15 \mathrm{mph}$. At the higher wind speeds there is greater potential for higher PM10 concentrations. PM10 concentrations are significantly higher, in the range of $25 \mathrm{ug} / \mathrm{m}^{3}$ to $50 \mathrm{ug} / \mathrm{m}^{3}$, and remain at these levels for significant portions of time when wind speed exceeds $15 \mathrm{mph}$. While these concentrations are relatively high they are still well below EPA PM10 standards $\left(150 \mathrm{ug} / \mathrm{m}^{3}\right)$ for hourly average.

Table 4 shows the PM10 concentrations by selected wind speed classes. For example, wind speeds of $0-5$ mph occur 57.1\% percent of time at the southern Plutonium Valley station and the average PM10 concentration for that wind speed class is around $9.6 \mathrm{ug} / \mathrm{m}^{3}$ and winds of 25-30 mph occur only $0.2 \%$ of time (or roughly 14 hours in a year) with the corresponding average PM10 concentration of $59 \mathrm{ug} / \mathrm{m}^{3}$; higher wind speeds are less frequent and corresponding PM10 concentrations during those periods are higher. Very similar trend can be seen for the Northern meteorological station at Plutonium Valley. 
Pu Valley Southern Met Station Average Hourly PM10

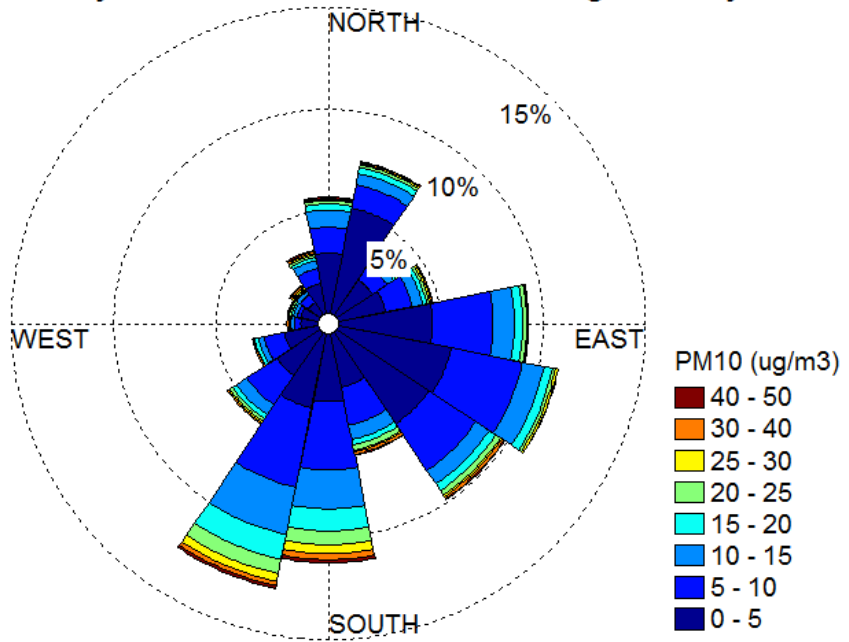

Pu Valley Southern Met Station Average Hourly PM10 for WS $>15 \mathrm{mph}$
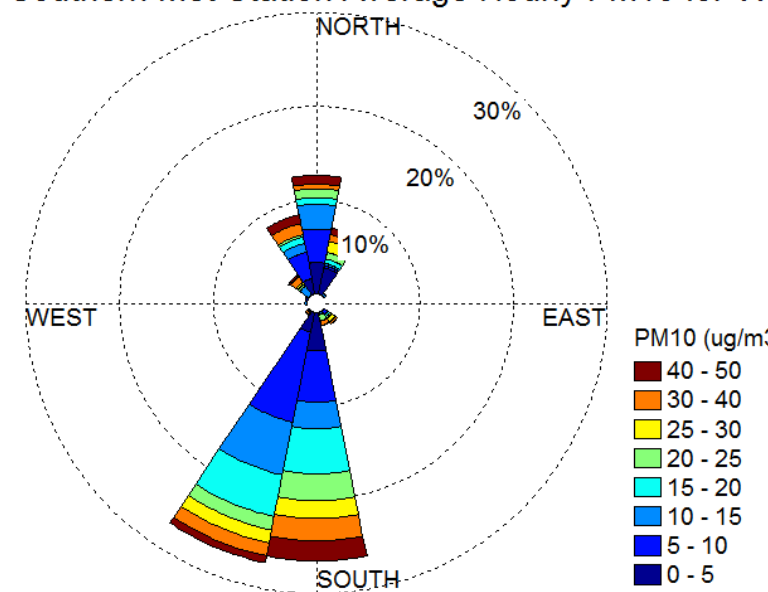

Pu Valley Northern Met Station Average Hourly PM10

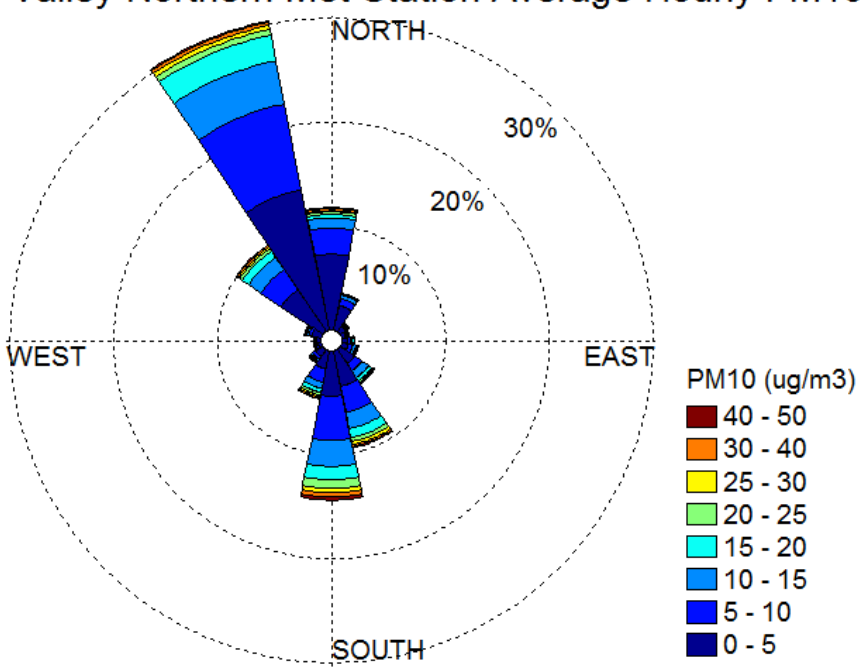

Pu Valley Northern Met Station Average Hourly PM10 for WS>15mph

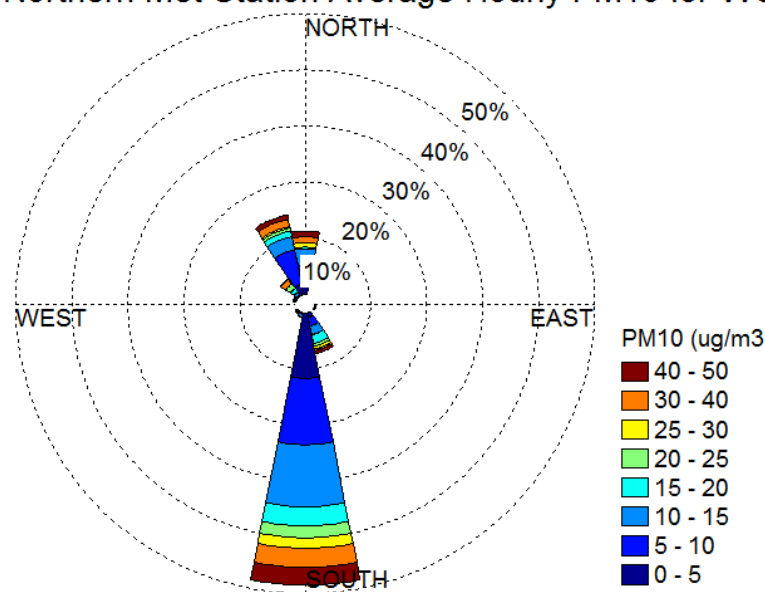

Figure 10. Rose diagrams illustrating the distribution of PM10 particles for the average hourly and average hourly greater than 15 mph wind conditions. 


\begin{tabular}{|c|c|c|c|c|}
\hline \multicolumn{5}{|l|}{ Pu Valley South Station } \\
\hline Wind Speed Class (mph) & Average WS (mph) & Average PM10 (ug/m3) & Duration (hr) & Fraction of Time \\
\hline 5 & 2.70 & \begin{tabular}{|l|}
9.59 \\
\end{tabular} & 4736 & 0.571 \\
\hline 10 & 7.24 & 9.89 & 2141 & 0.258 \\
\hline 15 & 12.13 & 13.68 & 999 & 0.120 \\
\hline 20 & 17.02 & 18.05 & 328 & 0.040 \\
\hline 25 & 21.86 & 50.06 & 76 & 0.009 \\
\hline 30 & 26.56 & 59.02 & 14 & 0.002 \\
\hline \multicolumn{5}{|l|}{ Pu Valley North Station } \\
\hline Wind Speed Class (mph) & Average WS (mph) & Average PM10 (ug/m3) & Duration (hr) & Fraction of Time \\
\hline 5 & 2.86 & \begin{tabular}{|l|}
8.89 \\
\end{tabular} & 4611 & 0.555 \\
\hline 10 & 7.23 & 10.24 & 2400 & 0.289 \\
\hline 15 & 12.11 & 11.91 & 912 & 0.110 \\
\hline 20 & 16.90 & 20.10 & 295 & 0.036 \\
\hline 25 & 21.85 & 42.50 & 72 & 0.009 \\
\hline 30 & 26.75 & 48.81 & 13 & 0.002 \\
\hline
\end{tabular}

Table 4. The duration of winds of a particular speed decrease and the associated PM10 concentration increase as the wind speed increases. 
Figure 11 illustrates the relationship between wind speed and PM10 concentration for the period of Aug 2011 to Aug 2012; it is clear that PM10 concentration increases in correlation with local wind speeds. The two stations show very similar trends in the relationship between PM10 and wind speed indicating that there are no significant dust sources between the two stations. It will be interesting to see if this changes at all in the next year since we observed some additional cleanup activities in the area this year that might result in some soil disturbance and possible increase in PM10 emissions during high wind events.

Figure 12 illustrates a high wind event that occurred at the southern station at Plutonium Valley between 11/30/2011 and 12/5/2011. Maximum sustained hourly wind speed (blue trace) almost reached $30 \mathrm{mph}$ and steady average speed (not shown) was around $20 \mathrm{mph}$ for extended time period early in the dust event. In the beginning and the end average wind speed was below 5 mph. The corresponding PM10 concentration (pink trace) was below $10 \mathrm{ug} / \mathrm{m}^{3}$ most of the time. It was only during the maximum wind speed that the PM10 concentration exceeded $250 \mathrm{ug} / \mathrm{m}^{3}$ for one hour. This figure illustrates the impact of high wind speed on the PM10 concentration and soil migration. Most of the transport events occur during short periods of time when wind is strong and exceeds the saltation threshold. The saltation threshold depends on many factors, including: soil water volumetric content, crust strength, and vegetation cover.

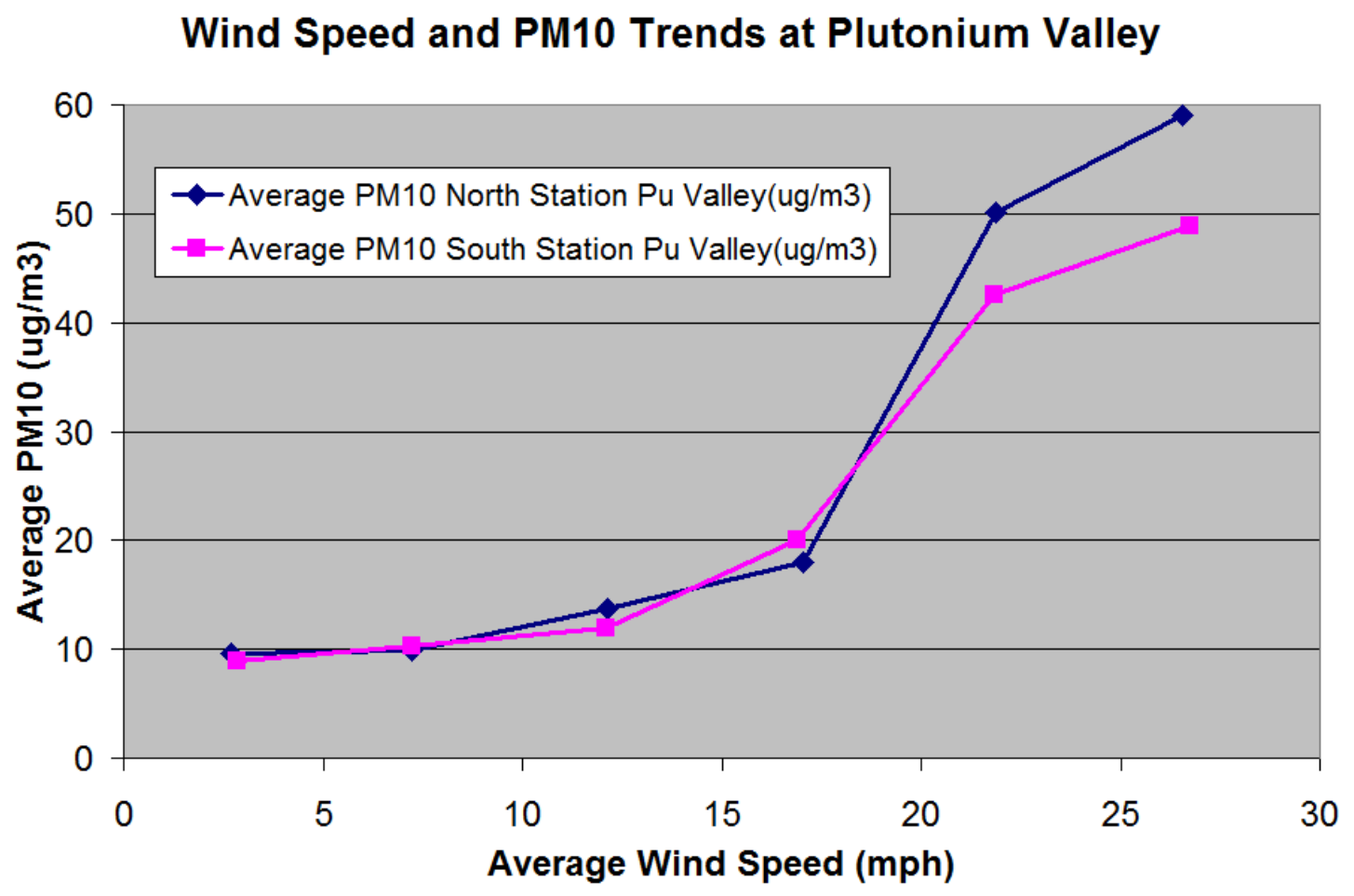

Figure 11. Comparison of wind speed and PM10 correlations reveals similar patterns at both the southern and northern Plutonium Valley meteorological stations. 


\section{High Wind and Dust Episode at Pu Valley}

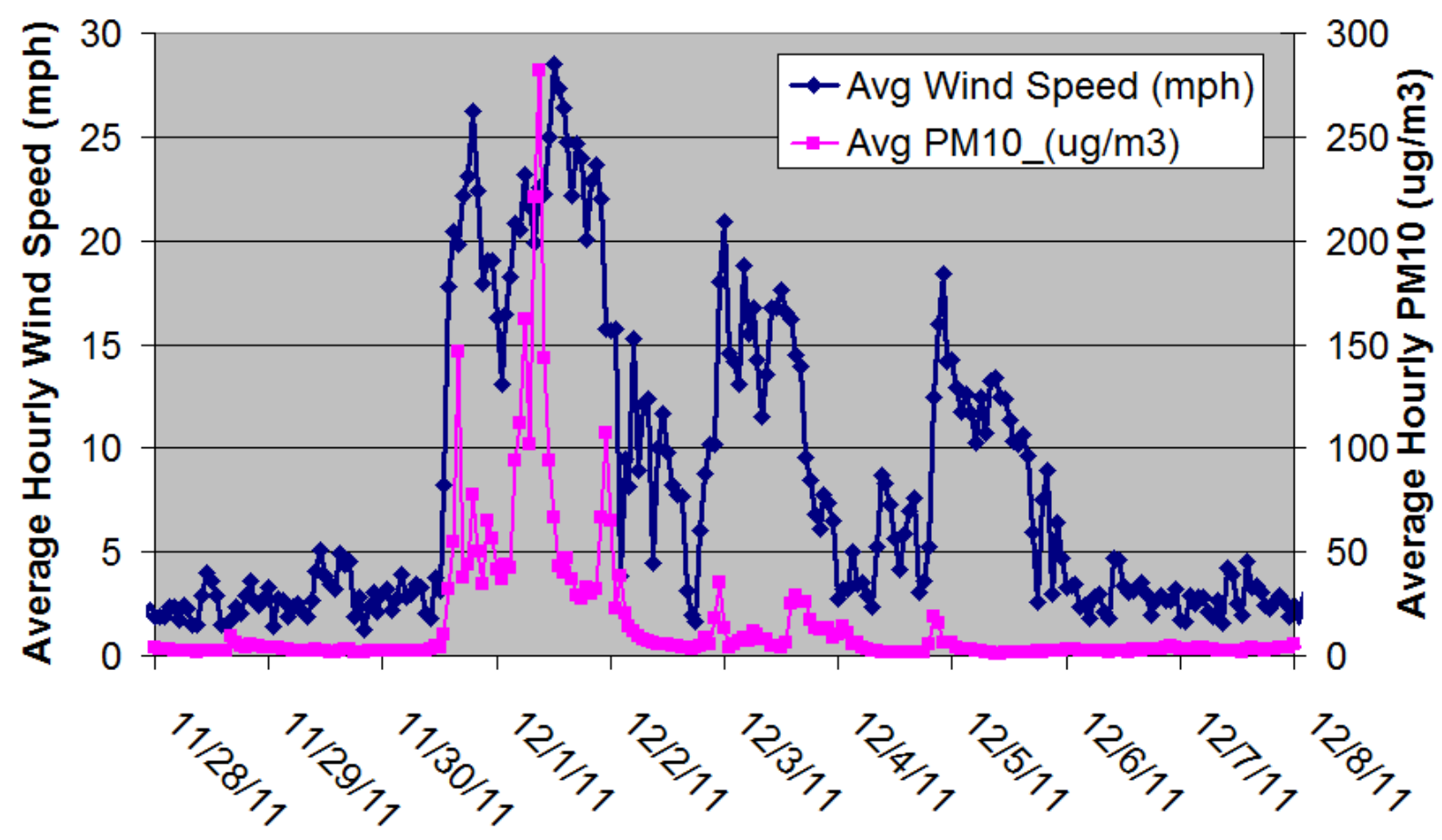

Figure 12. Observed hourly wind speed and PM10 values of a dust event in late November 2011 illustrate the complicated relationship between wind and dust concentration.

\section{FUTURE WORK}

Data transmitted from the Plutonium Valley site instrumentation will be reviewed monthly by project personnel to identify precipitation events that exceed the specified rainfall threshold $(\sim 0.2$ inches $[0.5 \mathrm{~cm}])$ and to assess proper operation of the instrumentation and remote communication equipment. Field inspections will be scheduled to service instrumentation only if necessary, because of budget limitations.

In response to a runoff event that triggers the ISCO sampler, project personnel will recover the collected water and bedload samples. These samples will be submitted to a specified laboratory for determination of particle size distribution and radionuclide concentrations. These data will help establish relationships between the sediment eroded and transported during runoff events and the significance of channel runoff as a pathway for migration of radionuclides from the CAU.

In addition, meteorological data collected leading up to and during the runoff event will be analyzed to characterize the meteorological conditions that produced the runoff. This analysis will help delineate threshold conditions that are likely to result in sediment transport and migration of radionuclides in conjunction with the sediment. Establishment of these thresholds will aid identification of meteorological conditions that will trigger monitoring and sampling of 
channel runoff migration pathways. Requirements for monitoring meteorological conditions and for sampling runoff pathways can then be appropriately incorporated in closure plans.

Note that sample collection and service work on the ISCO sampling equipment will require RCT support because the equipment is located inside the CA; this work will be scheduled as needed.

\section{REFERENCES}

Colton, D. 1999. A series of low-altitude aerial radiological surveys of selected regions within areas 3, 5, 8, 9, 11, 18, and 25 at the Nevada Test Site. DOE/NV/11718-362, prepared for the U.S. Department of Energy, Nevada Operations Office by Bechtel Nevada.

NNSA/NSO. 2009. Corrective Action Decision Document/Closure Report for CAU 370: T-4 Atmospheric Test Site, Nevada Test Site, Nevada, Rev. 0, May 2009.

Shinn, J.H., F.J. Gouveia, S.E. Patton, and C.O. Fry, 1993. Area 11 Case Study of Radionuclide Movement by Storm Channel Erosion: A Baseline Method and Initial Evaluation. Prepared for the U.S. Department of Energy, Nevada Operations Office, Las Vegas, NV. 
Appendix A - Period of Record Charts of Meteorological Observations at Plutonium Valley Station \#1

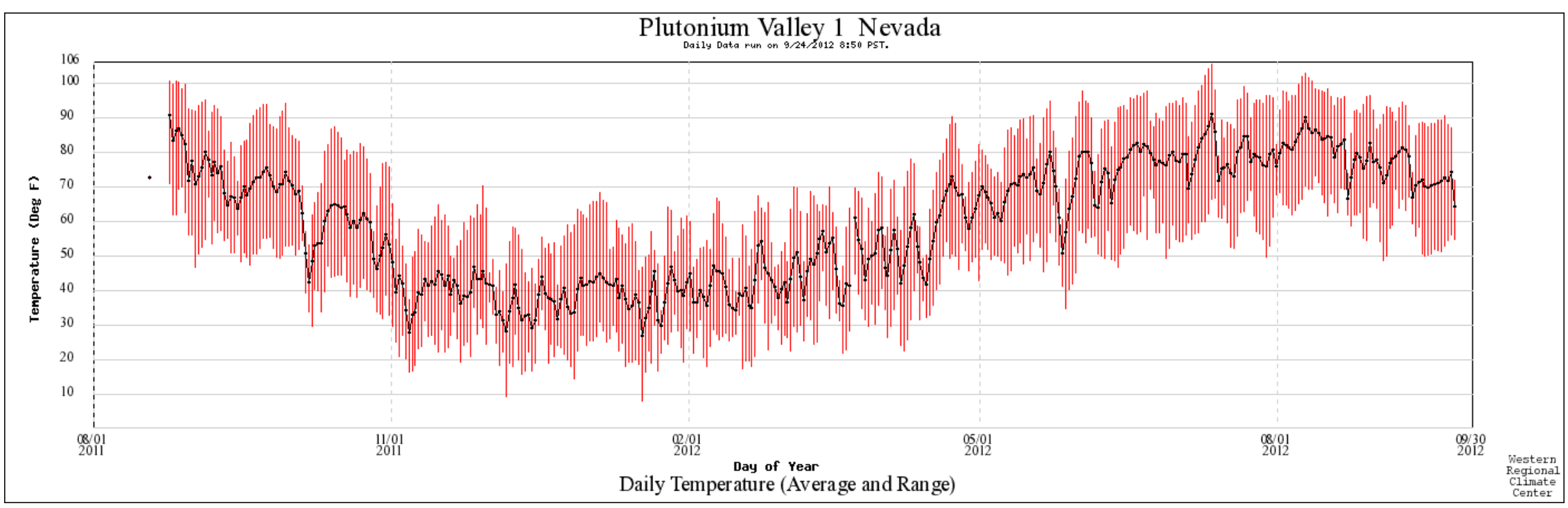

Figure A1. Daily average, maximum, and minimum air temperature evidence short term variations superimposed on the expected seasonal trend. 


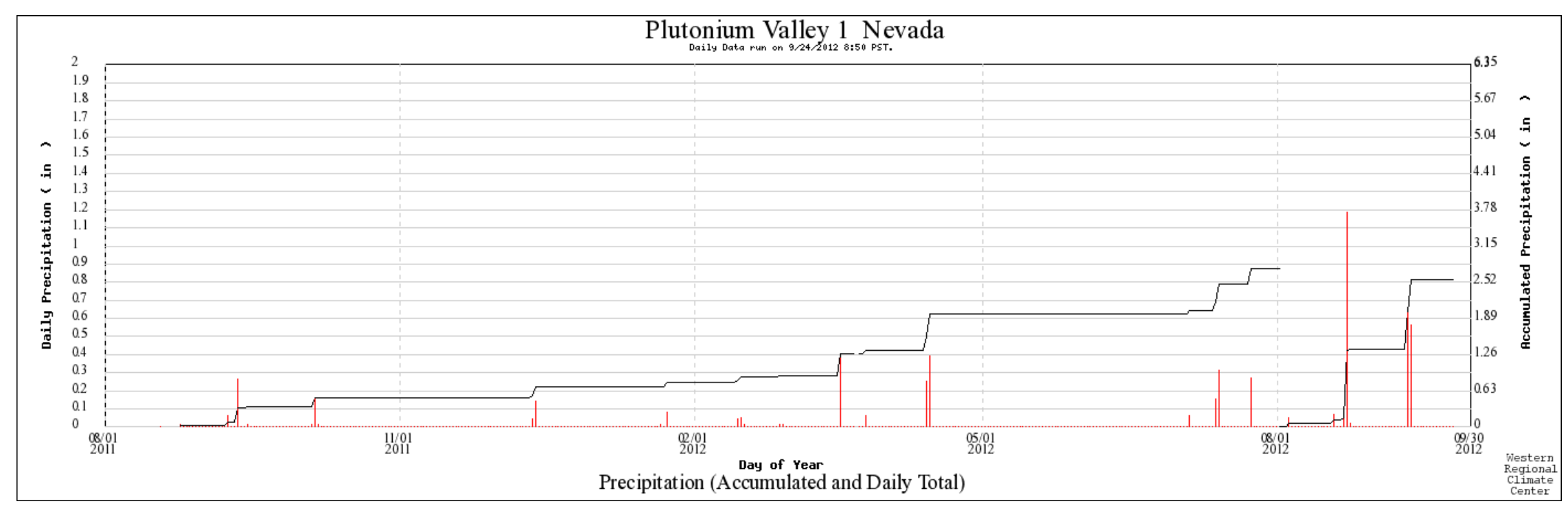

Figure A2.Precipitation exceeded 0.05 inches on 17 days during the period of record resulting in an accumulation of approximately 2.83 inches during the first 12 months of data collection and 5.38 inches for the period of record. 


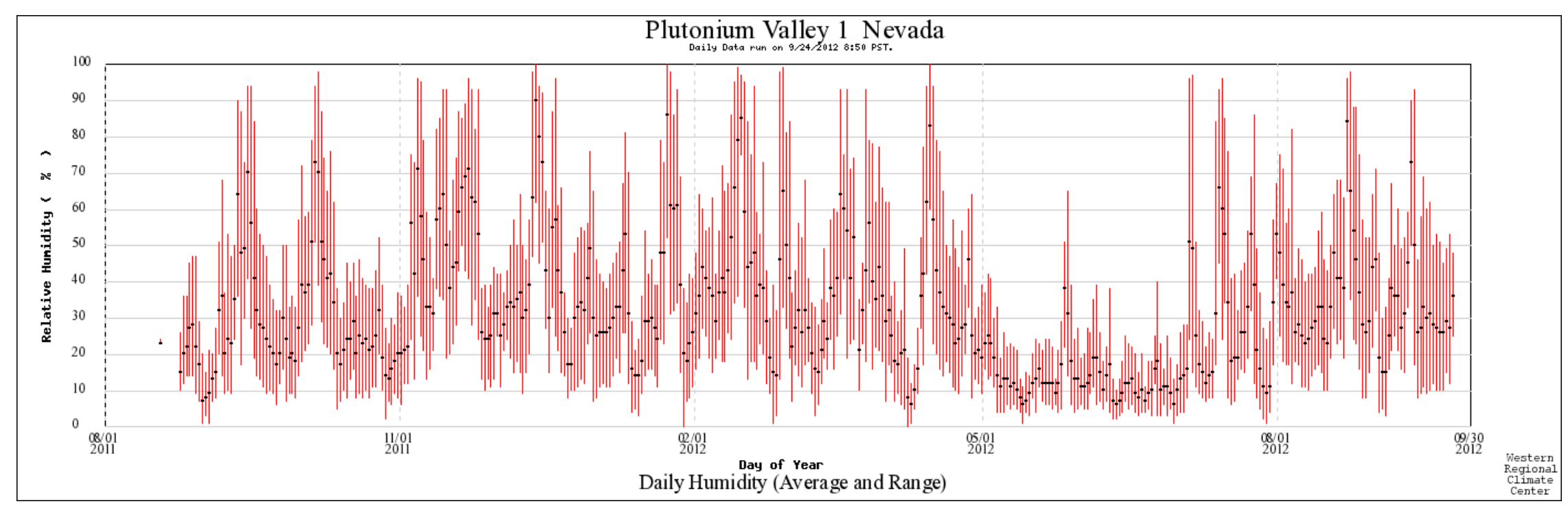

Figure A3. The relative humidity exceeded $80 \%$ on numerous occasions during the peri9d of record. In May and June 2012 the humidity was consistently below about $25 \%$. 


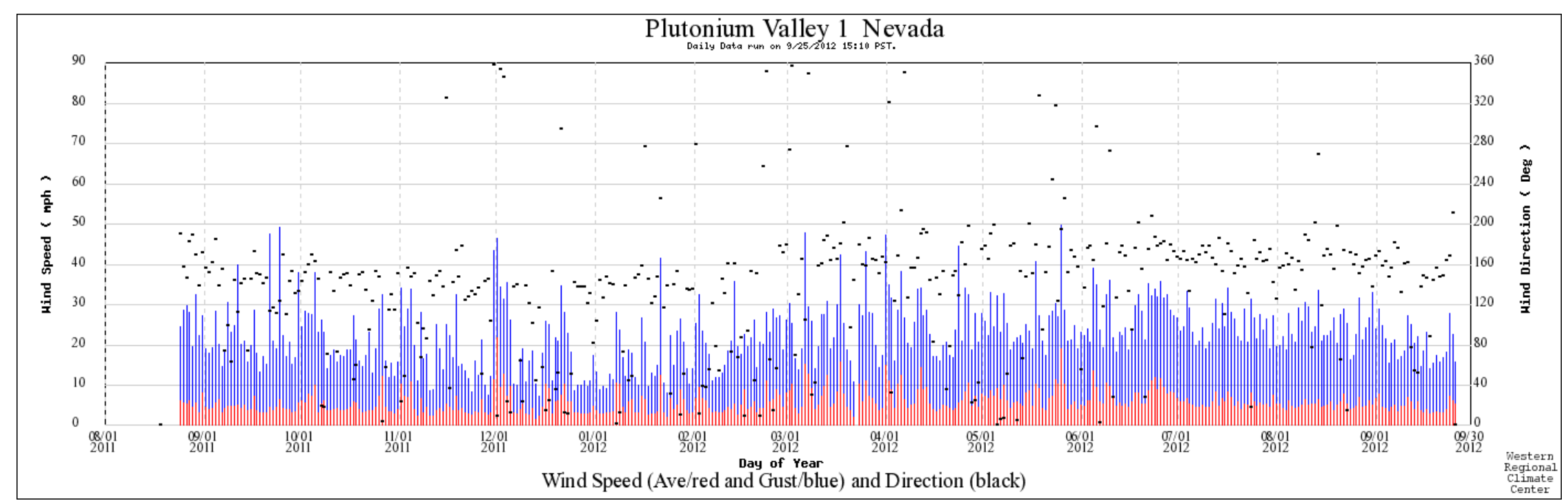

Figure A4. The peak wind speed reached $50 \mathrm{mph}$ in late May 2012 although on six other days during the period of record the wind speed exceeded $45 \mathrm{mph}$. Wind direction was predominately from the south throughout the period of record. 


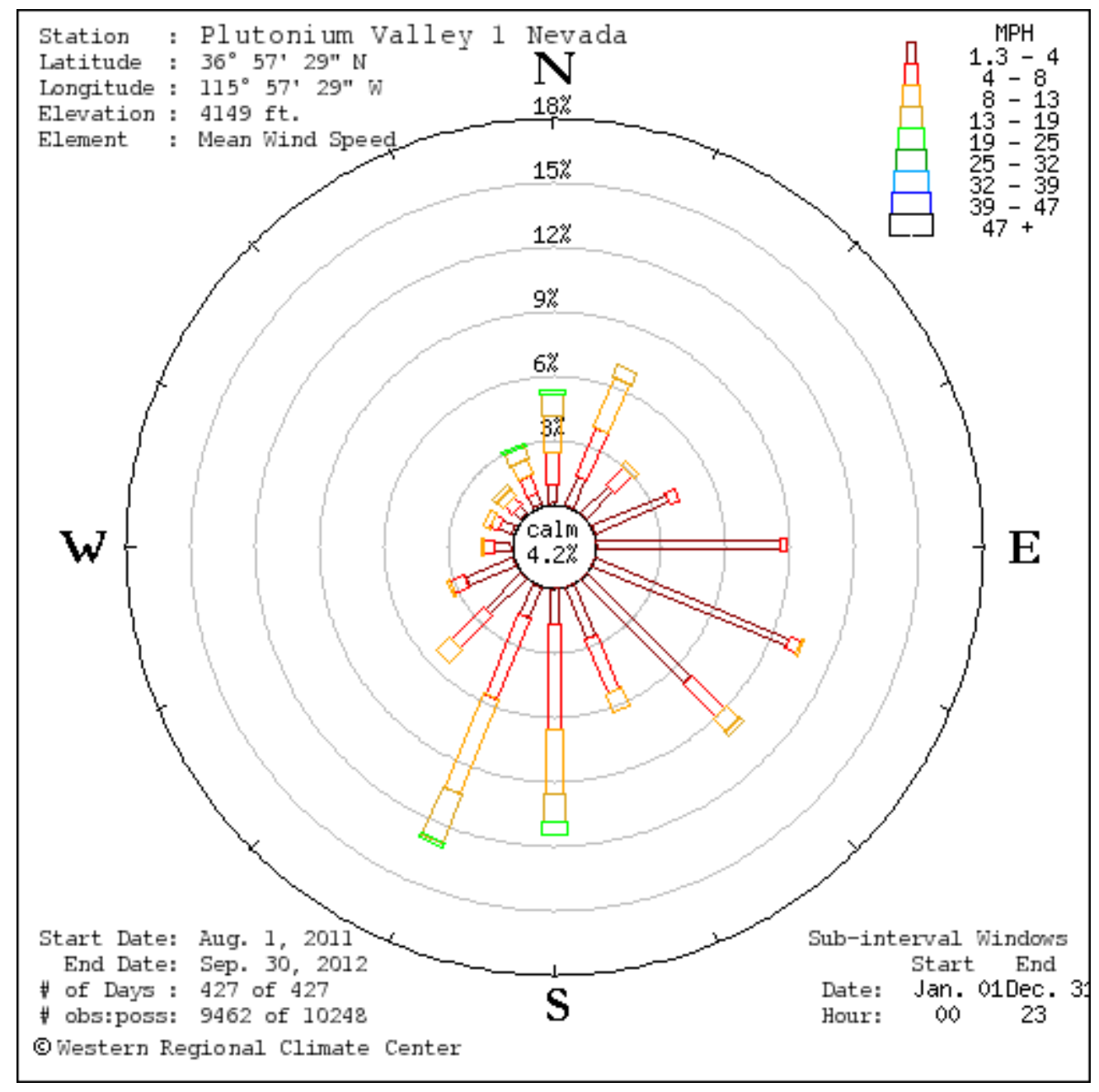

Figure A5. The wind rose shows stronger winds tend to come mostly from the south and south-southwest; less frequently they may also come from the north and north-northwest. Lighter winds from the east to southeast are common. 


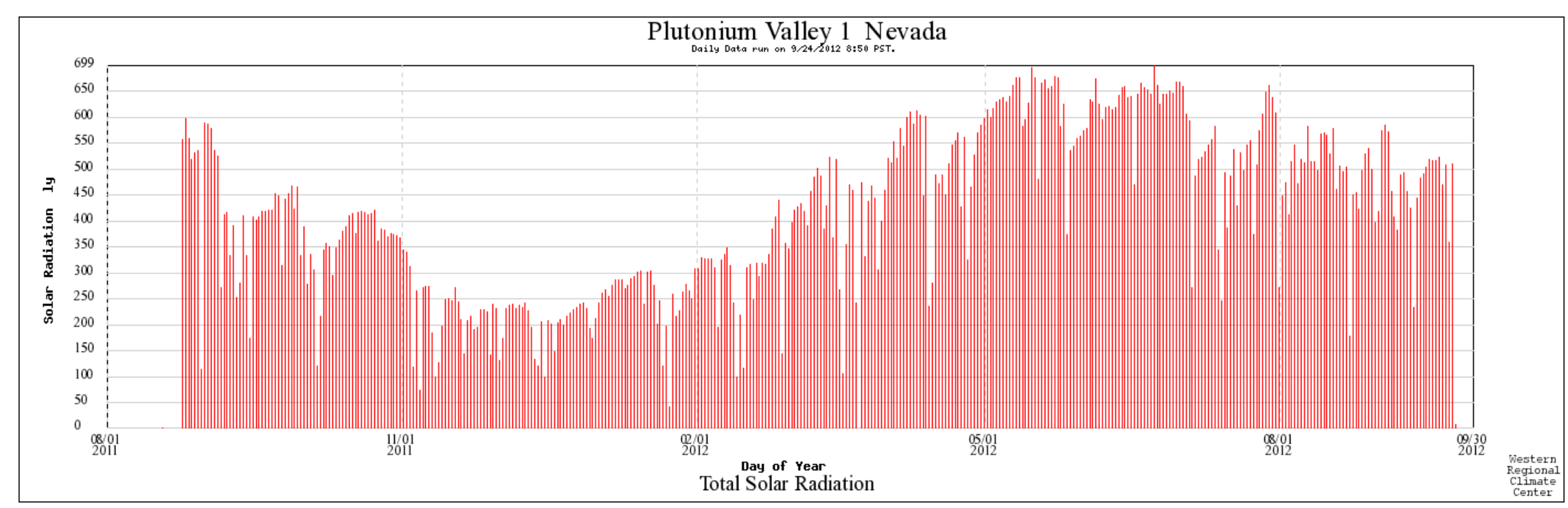

Figure A6. Solar radiation was greatest in the summer and lowest in the late fall and winter. 


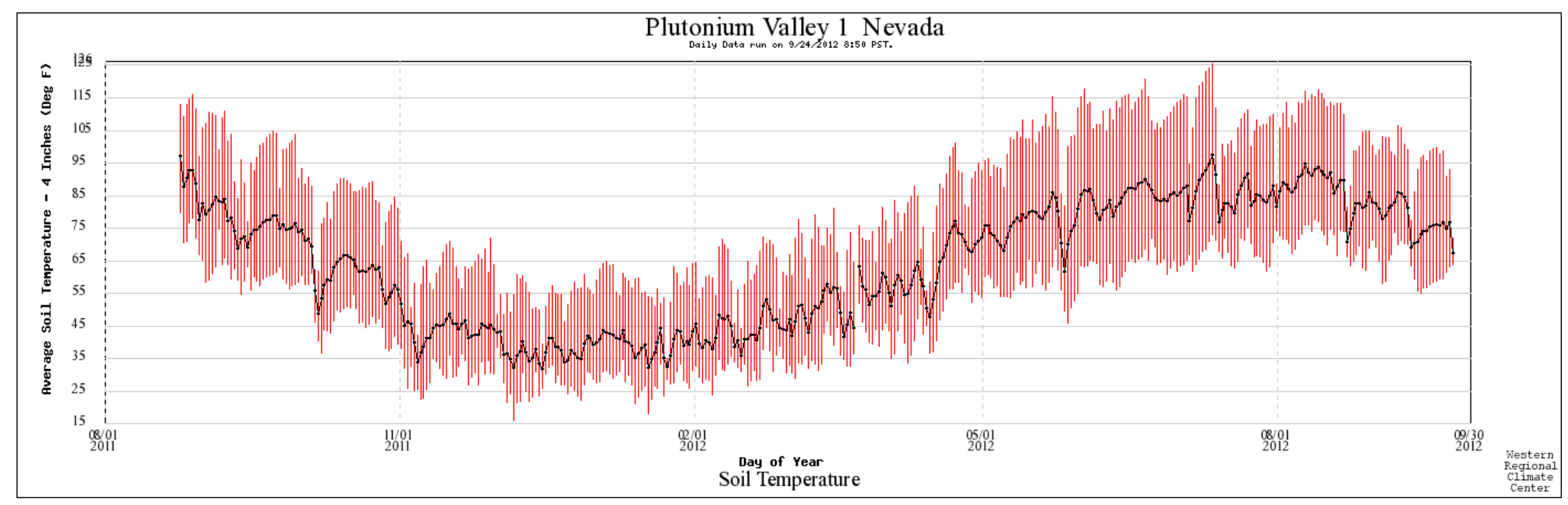

Figure A7. Soil temperature reflects a seasonal pattern similar to atmospheric temperature. 


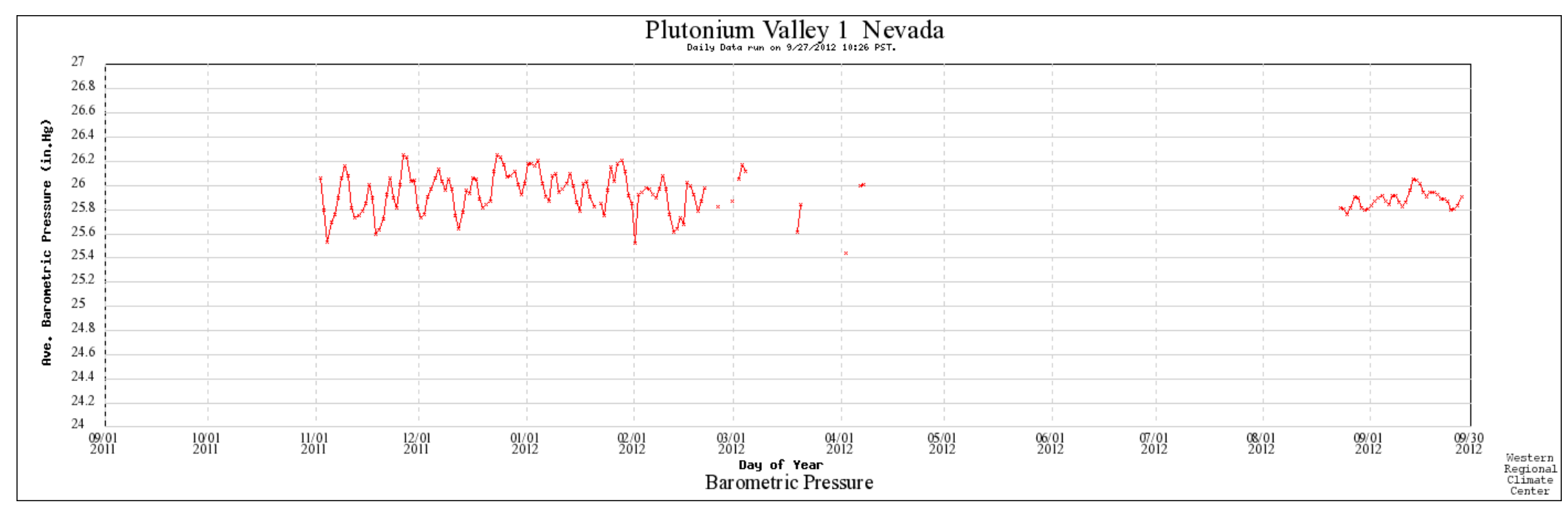

Figure A8. Barometric pressure sensor at Plutonium Valley south station (\#1) did not work properly throughout the period of record. 
Appendix B - Period of Record Charts of Meteorological Observations at Plutonium Valley Station \#2

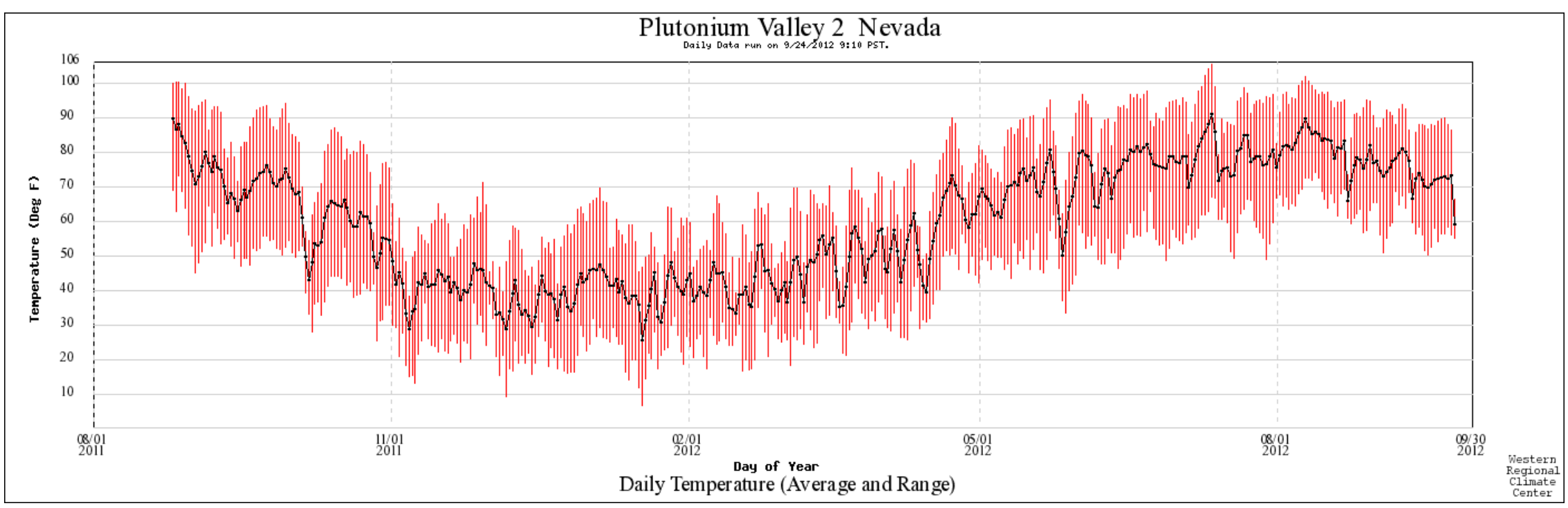

Figure B1. Daily average, maximum, and minimum air temperature evidence short term variations superimposed on the expected seasonal trend. 


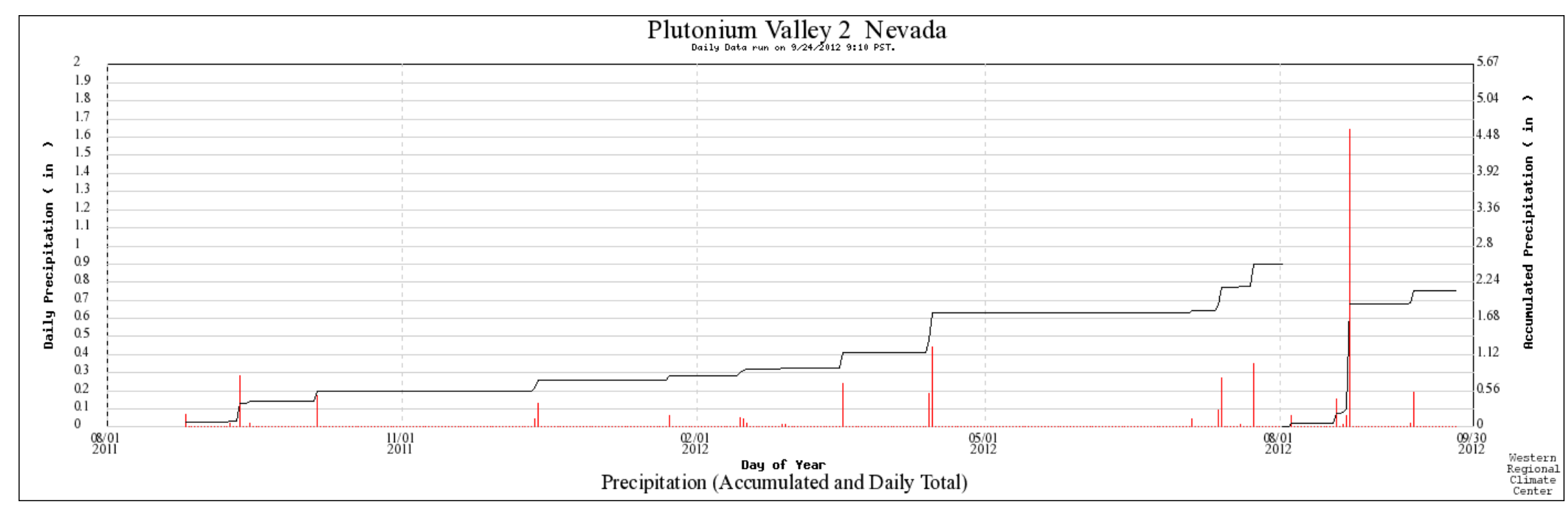

Figure B2.Precipitation exceeded 0.051 inches on 17 days during the period of record resulting in an accumulation of approximately 2.52 inches during the first 12 months of data collection and 4.62 inches for the period of record. 


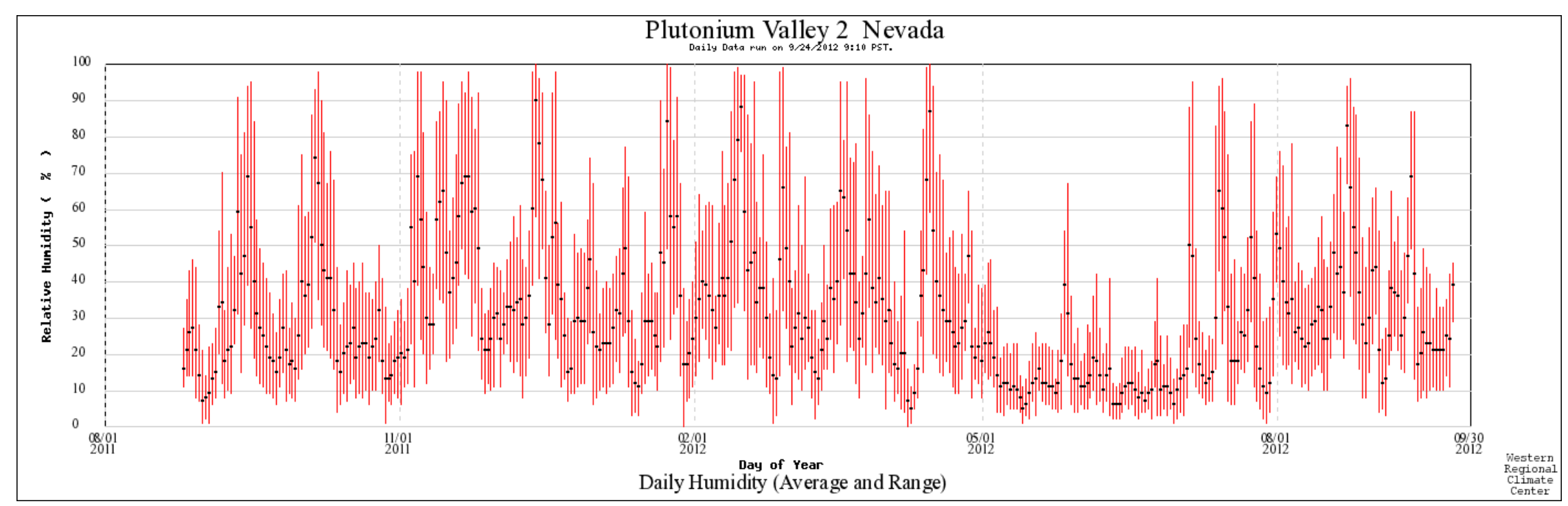

Figure B3. The relative humidity exceeded $80 \%$ on numerous occasions during the peri9d of record. In May and June 2012 the humidity was consistently below about $20 \%$. 


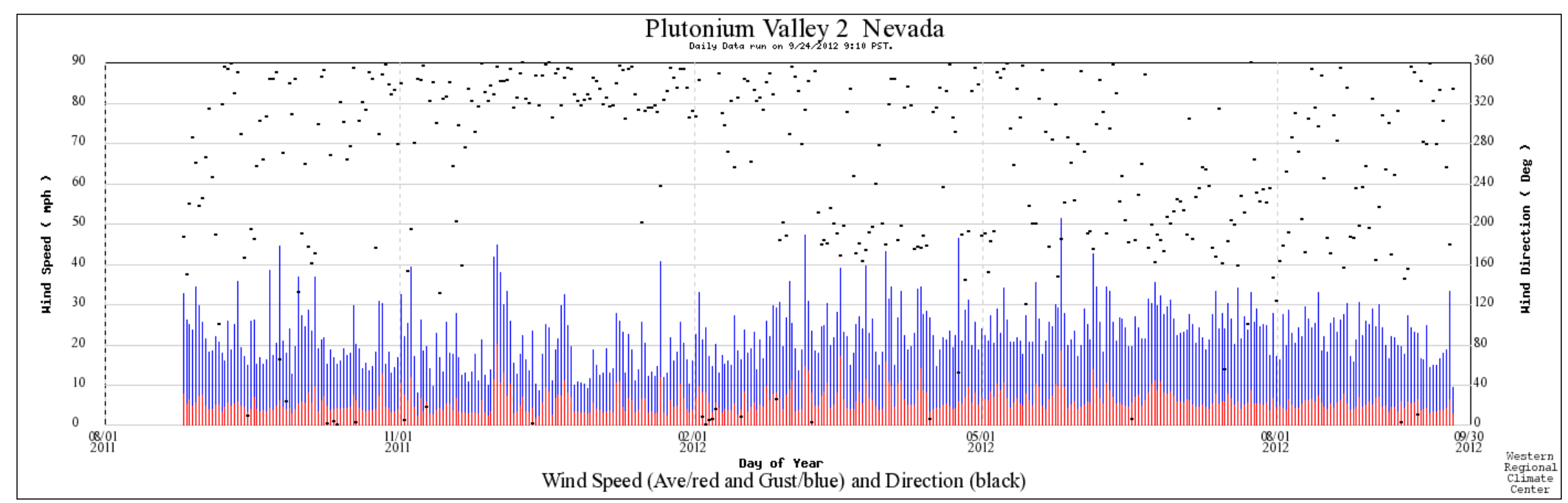

Figure B4. The peak wind speed exceeded $50 \mathrm{mph}$ in late May 2012; on eight other days during the period of record the wind speed exceeded $40 \mathrm{mph}$. Wind direction was predominately from the south in December and January. 


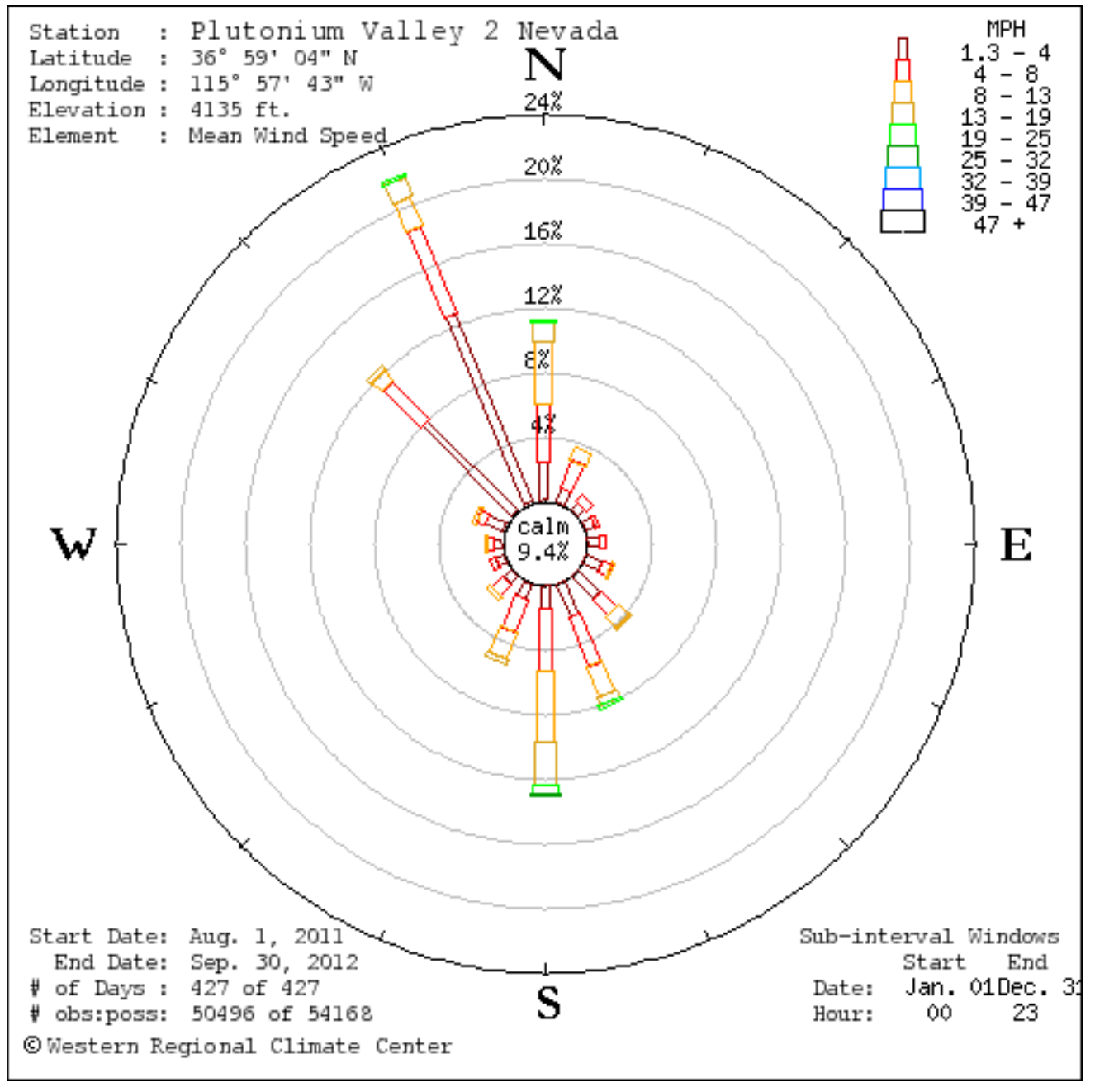

Figure B5. The wind rose shows stronger winds tend to come from the north-northwest and south-southeast with almost equal frequency. Lighter winds come from the northwest and south. 


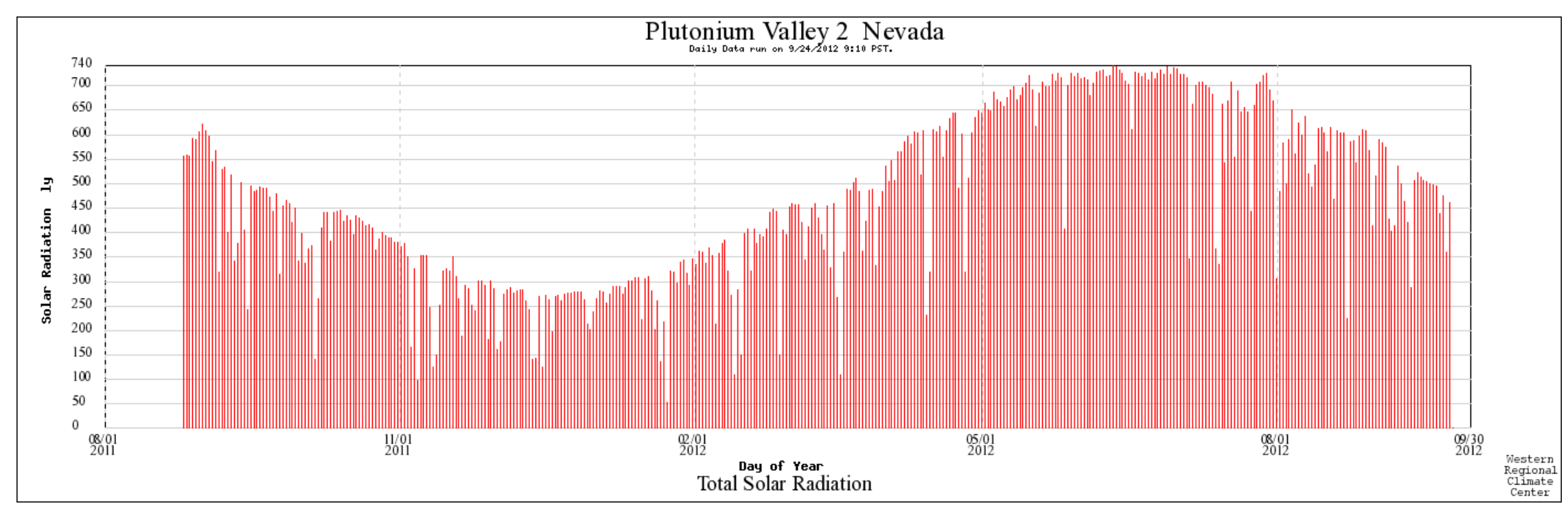

Figure B6. Solar radiation was greatest in the summer and lowest in the late fall and winter. 


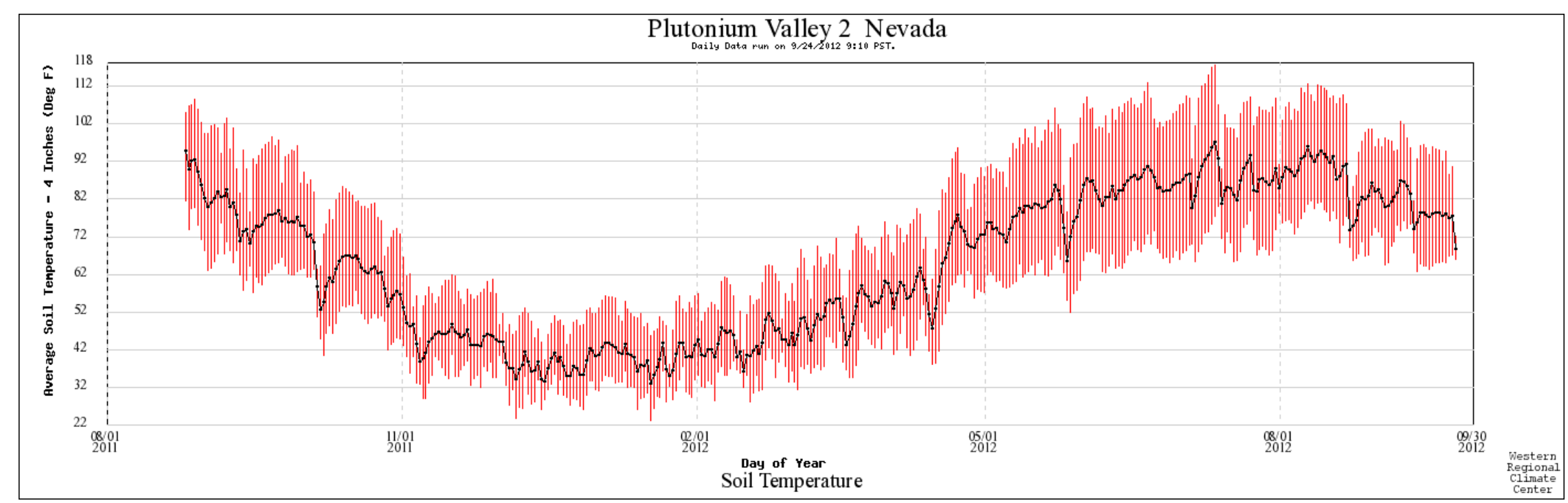

Figure B7. Soil temperature reflects a seasonal pattern similar to atmospheric temperature. 


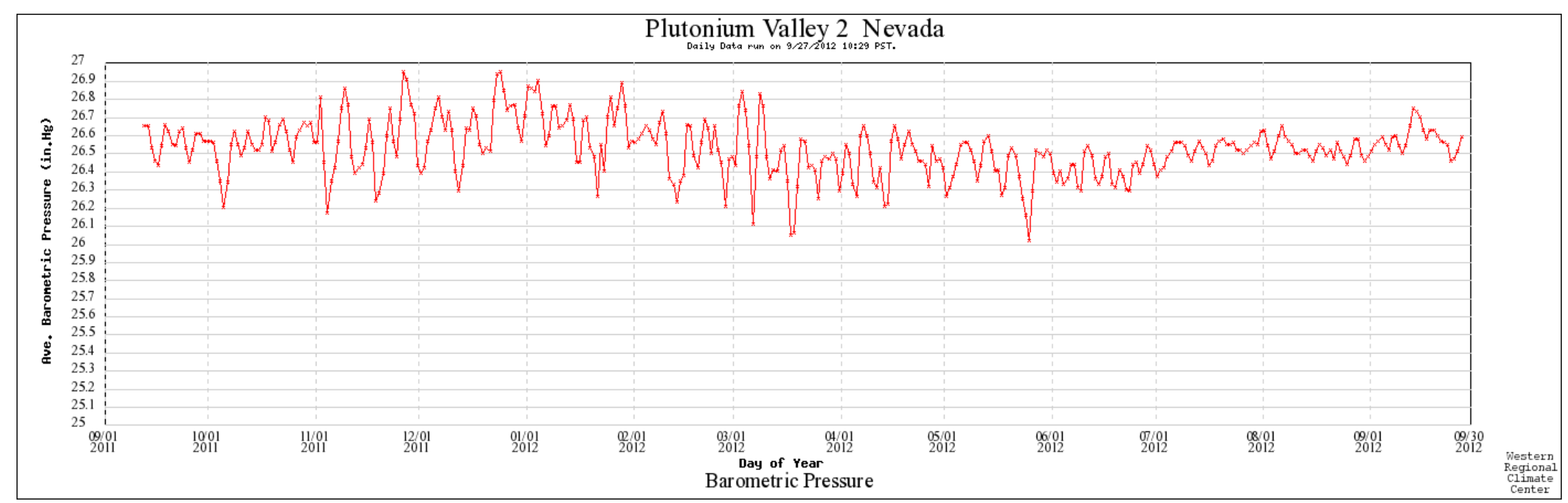

Figure B8. Barometric pressure at the Plutonium Valley north station (\#2) ranged between 26 and 26.95 inches of mercury. 